\title{
20. LATE CRETACEOUS AND CENOZOIC PELAGIC DEPOSITS - PALEOENVIRONMENT AND PALEOOCEANOGRAPHY OF THE CENTRAL WESTERN INDIAN OCEAN
}

\author{
Lucien Leclaire, Laboratoire de Geologie du Museum National d'Histoire Naturelle, Paris
}

\begin{abstract}
Pelagic deposits are the dominant contributors to the sediment layers that blanket ridges and basaltic sea floor in deep basins. Among pelagic constituents, nannofossils undoubtedly are the predominant contributor, especially to Cenozoic chalk and ooze. Among Leg 25 sites, the most typical pelagic deposits are found in the Madagascar Basin (Site 245) including a clayey nanno chalk, bearing $\mathrm{Fe}-\mathrm{Mn}$ oxides, resting directly on the basalt and overlain successively by a nanno chalk which is interlayered with chert and devitrified volcanic ash and a nearly pure nanno ooze. The lithologic sequence is capped by brown clay. Upper Cenozoic foram sand and foram nanno ooze were found on the Mozambique Ridge (Site 249) and particularly on the Madagascar Ridge (Site 246). Biogenic silica-rich facies are rare and mainly located near the top of the lowest latitude sites.

Descriptions of the major sedimentary facies lead to discussions and speculations about depositional conditions and hence about the Cenozoic paleoenvironment in the central western Indian Ocean. Important changes in paleoenvironmental conditions occurred throughout the Tertiary. Thus, increasing content in biogenic silica, together with greater foraminifera amounts in the Somali Basin and on the Davie Ridge, plus the occurrence of notable quantities of organic matter, are very likely connected to increasing productivity of the overlying water masses through late Cenozoic times. These facts are interpreted as corresponding to the gradual onset of the equatorial water mass circulation, whereas the change in redox conditions over the Davie Ridge area is believed to be related to the arrival of oxygen-depleted waters flowing southward from the Arabian Sea and Gulf of Aden. Formerly, during Eocene and Oligocene times, a great gyral circulation presumably supplied (at least partly) by the Pacific south equatorial current would have swept the southern Indian coast, which was then in the equatorial position, and would have been deflected southwards, thereby winnowing the Madagascar and Mozambique ridge sediments. The major cause of such changes in circulation would be the widening of the north central part of the Indian Ocean, i.e., the northward drift of India and the Carlsberg Ridge spreading associated with the gradual closing of the north Australian seaway.

Strong western boundary undercurrents supplied with Antarctic Bottom Water, presumably initiated by late Oligocene to early Miocene times, probably eroded large surfaces of the Somali, Mascarene, Madagascar, and Mozambique basins. They are considered to be the primary cause of important hiatuses in the sedimentary columns that encompass at least most of the Oligocene. These deep bottom currents would have been partially blocked by the uplift of the Southwest Indian Ridge in middle Miocene time; they still exist today as weak flows in the Mozambique, Madagascar, and Mascarene basins.

Paleodepths obtained by "back tracking" the age/depth constancy curve of the basaltic floor and paleontological data suggest important changes in the calcium carbonate compensation depth (CCD) and the associated foram-lysocline through Tertiary time. The last change is well marked by a relatively shallow lysocline that was followed by a sharp increase in depth in late Miocene time. This depth increase coincided with an acceleration
\end{abstract}


in sea-floor spreading and may have originated by volcanogenic supplies and the weathering of basaltic crust in contact with seawater which lead to the removal of great quantities of calcium from fresh basalts.

\section{INTRODUCTION}

\section{Objectives}

The major objectives of this chapter are the following: (1) to gather data about pelagic sediments in one chapter; (2) to emphasize the pelagic deposit contribution to the sediment columns of ridges and basins; and (3) to test the spreading sea-floor hypothesis with regard to changes in pelagic sedimentation, and thereby to draw attention to major changes in paleoenvironmental conditions through Cenozoic time in the central western Indian Ocean. The first two points are restricted more or less to facts, but the third is open to reasonable interpretations and speculations based on these facts.

A major difficulty in this study is the great diversity of drilling sites (Figure 1) that are situated on ridges and in basins each of which really constitutes a particular problem. This diversity certainly limits global correlations of current changes and sea-floor spreading phenomena. However, some facts gathered here give strong evidence for changes in circulation patterns, deepening and shallowing of the sea floor, and large-scale horizontal movements of the continents and sea floor. The reader is reminded that many interpretations formulated and discussed in this report are somewhat speculative and need much more checking. However, it is emphasized that the findings from studies of this part of the world oceans support the contention that pelagic sedimentation has been strongly influenced by sea-floor spreading phenomena.

\section{Methods}

The single most important data source for the present account is the shipboard Hole Summary Book, especially the lithology and paleontology parts which were prepared during the Leg 25 cruise and later revised on shore. Additional material comes from post-cruise laboratory work in Paris, mainly calcium carbonate determinations, smear slide analyses, and scanning electron microscope investigations.

\section{PELAGIC DEPOSITS IN THE LITHOLOGIC SEQUENCES}

\section{Definition and Classification}

Before dealing with specific deposits at the drilling sites, it is necessary to define the meaning of "pelagic sediments." Moreover, because a classification forms the basis for genetic interpretations, the classification used here is explained.

"Pelagic" comes from the greek "pelagos" which means sea. By extension, the general use designates all things related to the oceanic environment as pelagic; examples are pelagic fauna and pelagic sediments. Pelagic sediments, land-derived or terrigenous deposits, and volcanic sediments constitute the basis for several classifications of marine sediments.

Attempts to classify pelagic sediments have been based either on appearances and compositions, or on the origin of the components. The later scheme has been applied by Arrhenius (1963). Although the origin of most biogenous components is generally obvious, the origin of the major nonbiogenous components has not been established with certainty in most areas. It appears feasible to distinguish minerals which crystallize in oceanic waters from those which originate, for instance, in basaltic magmas and hydrothermal solutions. Minerals which arise from oceanic water are described, according to Arrhenius (1963), as "halmeic" (from seawater). The components derived from exposed continental surfaces are here designated as terrigenous. Part of the terrigenous fraction undergoes slight modifications which are more or less related to ion-exchange capacity and to the very long passage of time through oceanic waters. This part (mostly clay minerals) is mixed with a major nonaltered mineral fraction and in some places with an authigenic fraction (for example, authigenic clay minerals). Relative proportions of the components generally are unknown and are difficult to determine. This mixture of components is named hemihalmeic. Minerals emplaced in the ocean by volcanic activity are described as volcanogenic. Tests secreted by living organisms are referred to as biogenous. Biogenous and halmeic components are truly pelagic in origin. Other components, land derived and volcanogenic, are allochthonous. The classification used here is mostly that of Arrhenius (1963) and is summarized in Table 1.

Because pelagic deposits generally contain a terrigenous fraction, one can expect that it is possible to find deposits intermediate between pelagic and terrigenous. These were designated as hemipelagic by Kuenen (1950). Distinction as to whether a deposit is classified as pelagic or hemipelagic is based on the sedimentation rate. According to Arrhenius (1963), "In the basins accumulating pelagic sediments, the terrigenous deposit rate appears to vary not much more than one order of magnitude $\left(5 \times 10^{-5}\right.$ to $5 \times 10^{-4} \mathrm{~cm} /$ year $) . "$ This is very low when compared to sediment accumulations in basins fringing the continents. In other words, a rate of terrigenous deposition not higher than $5 \mathrm{~m} / \mathrm{m} . \mathrm{y}$. seems to characterize and, to some extent, define pelagic deposits.

Volcanic contributions are generally minor in pelagic deposits, and in most instances they are considered as pelagic components. However, when they are dominant, the sediment can no longer be logically referred to as pelagic but rather as volcanogenic (or pyroclastic). 


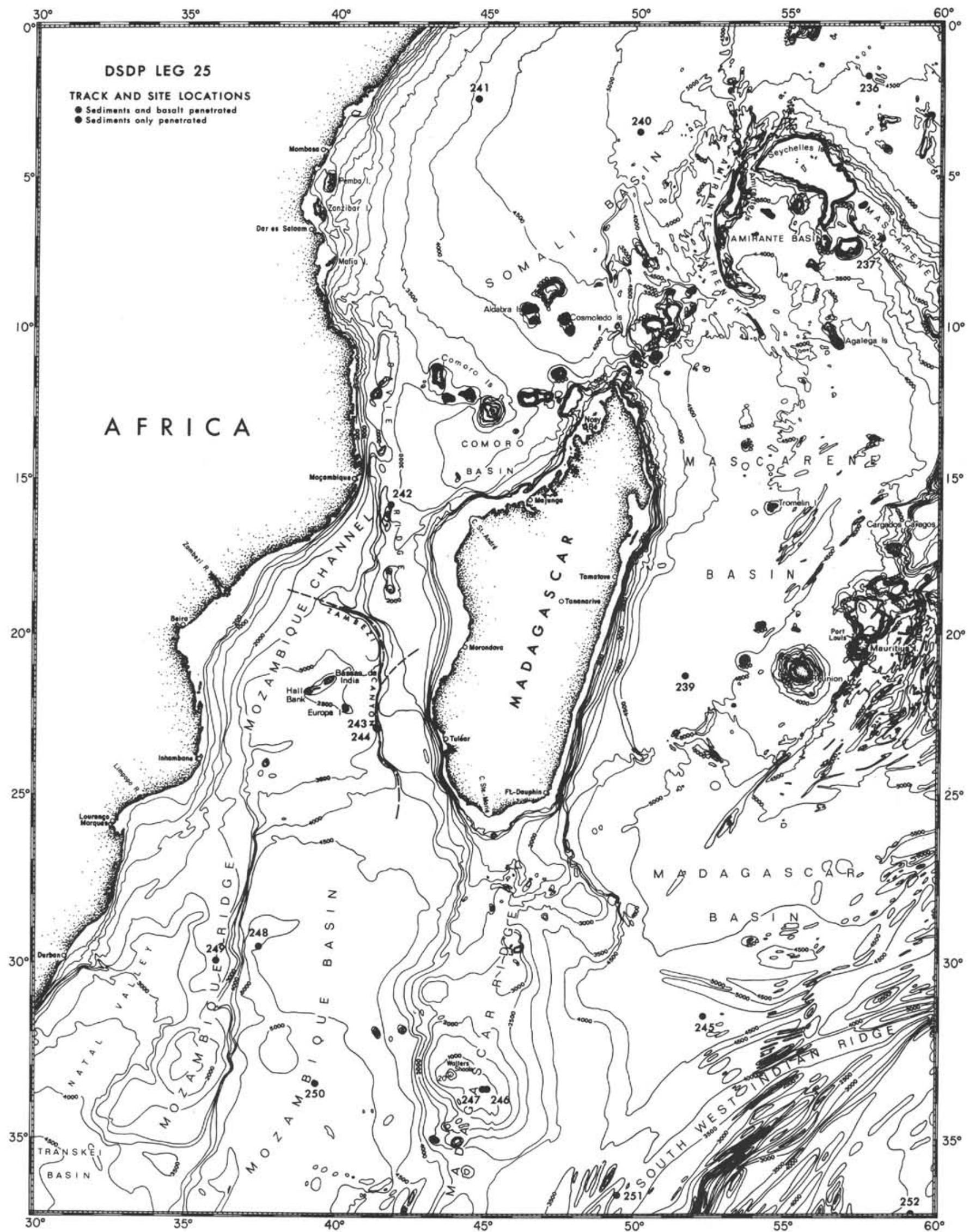

Figure 1. Index map showing the Leg 25 drilling sites. 
TABLE 1

Pelagic Deposit Classification

(Mostly from Arrhenius, 1963)

\begin{tabular}{ll}
\hline Nature of Particles Deposited & Components Groups \\
\hline $\begin{array}{l}\text { Foraminifera, nannofossils, } \\
\text { sponge spicules, radiolarians }\end{array}$ & $\begin{array}{l}\text { Biogenous (biogenic) } \\
\text { components }\end{array}$ \\
$\begin{array}{l}\text { Zeolites, pyrite, Mn-Fe oxides } \\
\text { Long passage time clay }\end{array}$ & $\begin{array}{l}\text { Halmeic components } \\
\text { minerals }\end{array}$ \\
$\begin{array}{l}\text { Land-derived detrital } \\
\text { particles }\end{array}$ & $\begin{array}{l}\text { Terrigenous } \\
\text { components }\end{array}$ \\
$\begin{array}{l}\text { Volcanic glass, shards, } \\
\text { devitrified volcanic clays }\end{array}$ & $\begin{array}{l}\text { Pyroclastic (volcano- } \\
\text { genic components) }\end{array}$ \\
\hline
\end{tabular}

\section{Pelagic Deposits at Leg 25 Sites}

Using shipboard smear-slide analyses, along with complementary smear-slide investigations in the shore laboratory, a diagram has been constructed (Figure 2). Obviously, such analyses provide only semiquantitative data, but they are sufficient, in a preliminary attempt, to broadly outline the relative contribution of pelagic sedimentation to the sediment column at each site. Pelagic components are very important contributors to the sedimentary blanket that was cored in the central western Indian Ocean.

At Site 239, in the Mascarene Basin, the sediment column consists of about 50 percent pelagic deposits. Although the top of the lithologic series (subunit IA) consists of minor clayey nanno ooze, subunit IB is mostly clay-rich nanno ooze and subunit IC is a mixture of terrigenous detrital deposits and carbonate-rich nanno ooze. In some intervals, part of the clay fraction may be considered as pelagic because of the high amount of montmorillonite (50\%-60\%). Below 150 meters, the sedimentary column consists predominantly of mixed detrital silty clay and nanno clay. This sediment can be referred to as hemipelagic (Moore, this volume). From 280 meters down to the basalt, the major lithology is brown clay which has an important volcanic contribution. Nanno ooze is interlayered with the brown clay, part of which might be detrital (pelagic turbidites).

At Site 240 in the Somali Basin, the lithologic sequence is mostly detrital (terrigenous sand and silt). However, a notable pelagic sediment contribution occurs at the top of the sequence as nanno rad ooze and at the bottom as nanno ooze and carbonate-rich nanno ooze. Site 241 , drilled in sediments which fringe the East African continental margin, displays a lithologic record characterized by two units. The upper one, from the top down to 470 meters, consists dominantly of pelagic components (mostly nanno ooze mixed with some detrital clay). Certain interlayered beds, apparently of pelagic origin, are redeposited sediments which had been transported by turbidity currents. Below this sequence (lower unit), flysch-type detrital sediment and rock compose the lithologic column. Hence, at least one-third of the sedimentary sequence, from the upper Oligocene to Pleistocene, consists mainly of pelagic deposits.
On Davie Ridge, at the northern entrance of the Mozambique Channel, the lithologic record obtained at Site 242 is characterized by remarkably similar sediments throughout the cored interval. These deposits contain from 45 to 70 percent of calcareous biogenic deposits mixed with an important clay fraction (30\%-50\%). Typically, this kind of deposit is considered to be hemipelagic with the pelagic part dominant.

Further south, sediment on the bottom and flanks of the Zambezi Canyon is devoid of notable pelagic contribution, products of which were either diluted or more likely winnowed away, as shown by sediments recovered at Sites 243 and 244. Similarly, the floor of the Mozambique Basin (Site 248) is covered with a thick terrigenous sequence except at the very top (upper Pliocene-Pleistocene) where pelagic sediments are dominant and at the bottom where brown clay overlies basalt.

The most complete and typical oceanic pelagic sequence drilled during Leg 25 was at Site 245 in the Madagascar Basin. The whole sedimentary column consists mainly of nanno ooze and nanno chalk with some brown clay in the upper part. Only a few detrital beds of clay and silt are interlayered; the dominantly pelagic sequence and brown clay contain a minor detrital silt fraction. Near the bottom of the sequence, part of the nanno chalk contains clay and chert which probably originated through the devitrification of volcanic components.

At Site 246, on the Madagascar Ridge, a relatively thick $(130 \mathrm{~m})$ coarse-grained sequence was cored. Foram sand and ooze accumulated during Miocene, Pliocene, and Quaternary times. These sediments, in spite of some detrital influence, can be considered as pure pelagic deposits capping the Madagascar Ridge.

Nanno ooze and nanno chalk comprise about two-thirds of the whole sedimentary sequence resting upon basalt on the Mozambique Ridge. The upper part ( $32 \mathrm{~m}$ thick) consists mainly of pure foram-rich nanno ooze whereas the lower part (down to $172 \mathrm{~m}$ ) contains 10 to 20 percent detrital clay. Below the hiatus that occurs between middle Miocene and Upper Cretaceous sediments, the major lithology is foram-bearing clay-rich nanno chalk which shows a general increase in clay content when compared to the upper part.

On ridges, on fringes of continental margins, and in basins, sedimentation in the central western Indian Ocean throughout Cenozoic time is characterized by major pelagic contributions. This fact is rather unexpected considering the proximity of continental land masses, i.e., East Africa and Madagascar.

\section{Distribution of Pelagic Components}

\section{Biogenous Components}

\section{Calcareous Nannofossils}

Of all the pelagic components, nannofossils are the most abundant and main contributors to the sediment columns. Not only are they the dominant pelagic component in many Leg 25 oozes and chalks, but also they are dominant in many sites previously drilled in the world oceans. Since 

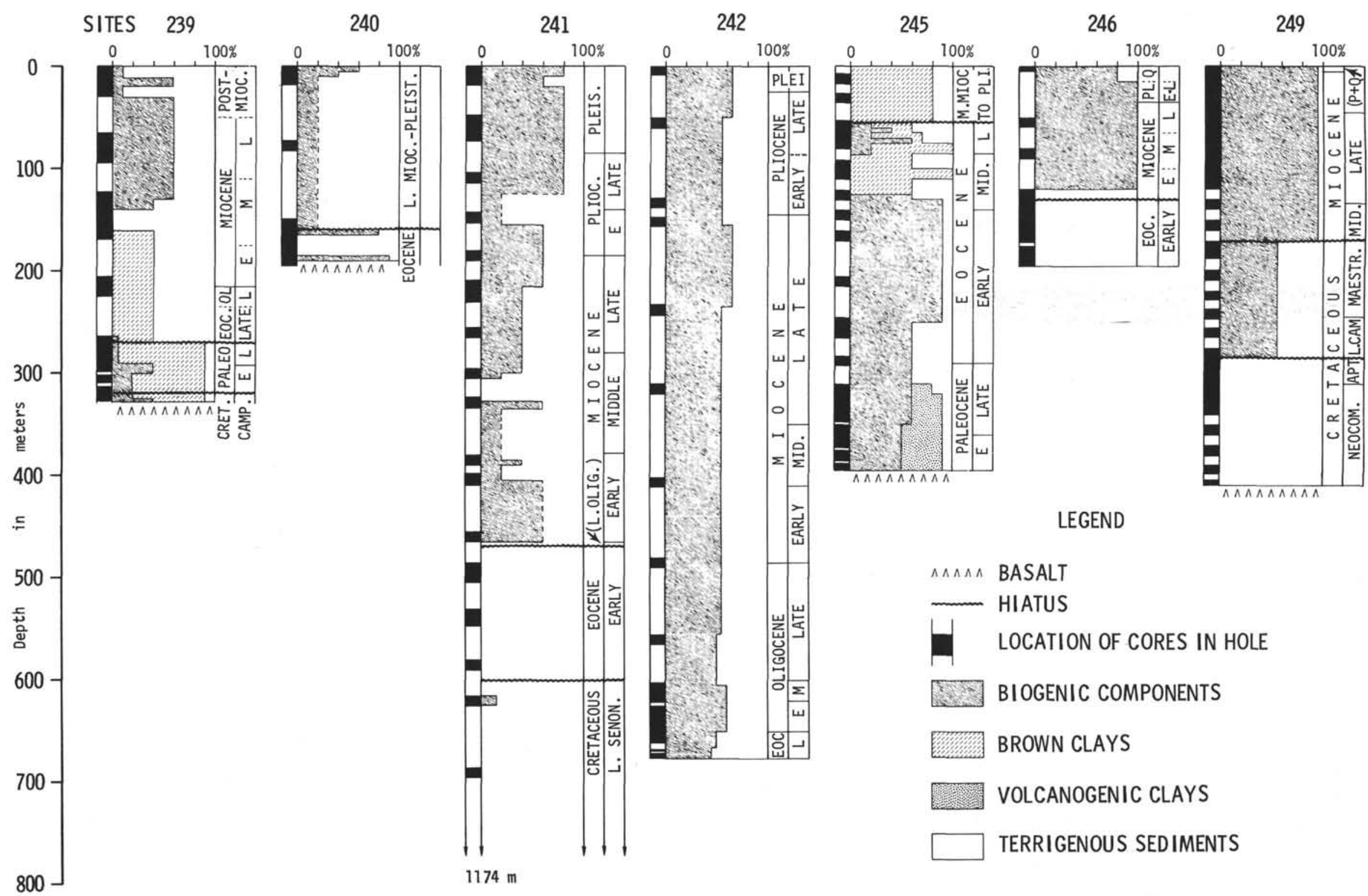

Figure 2. Pelagic deposits contribution to the sediment columns cored during Leg 25 . 
the beginning of DSDP operations, one leg after the other, coccolithophorids and discoasters have apparently been the most important contributors (volumetrically) to ocean deposits. The contribution of these algae was recognized many years ago (Cayeux, 1935; Bramlette, 1958).

In the extreme western Indian Ocean, on the Mozambique Ridge (Site 249), abundant nanno ooze accumulated throughout late Miocene time. Above 100 meters depth at Site 249, nannofossils comprise, on the average, from 60 to 70 percent of the sediment bulk; above 60 meters depth their amount reaches 85 to 90 percent (Figures 2 and 3 ) and then constitute most of the calcium carbonate fraction. Figure 4 clearly shows a greater content in nannofossils mainly from early late Miocene through most of late late Miocene. The relative rate of biogenic sedimentation is about $18 \mathrm{~m} / \mathrm{m}$.y. which is fairly high when compared to the absolute rate of sedimentation of 24 $\mathrm{m} / \mathrm{m} . \mathrm{y}$. During the middle Miocene, the nannofossil sedimentation rate was not higher than $5 \mathrm{~m} / \mathrm{m}$.y. Below the hiatus between Late Cretaceous and middle Miocene that breaks the stratigraphic column, the calcium carbonate content decreases abruptly (Girdley, this volume; Table 2) which is connected with a sharp decrease in the nannofossil content to 40 to 50 percent. Below the second hiatus, between Cenomanian and late Campanian, they nearly disappear (Figure 4). Throughout this pelagic sequence, nannofossils are well preserved, which indicates that the CCD was far below the depositional depth.
On Davie Ridge (Site 242), coccolithophorids and discoasters comprise about 50 percent of the sediment bulk in the upper Eocene through Pleistocene sediments. Nanno content increases slightly through late Miocene time where it reaches 60 percent and then decreases upwards (40\% through Plio-Quaternary) (Figures 3 and 4, Table 3). The nannofossil sedimentation rate reached 20 to $25 \mathrm{~m} / \mathrm{m}$.y. during the late Miocene which is surprisingly high compared to the middle Miocene $(2 \mathrm{~m} / \mathrm{m} . \mathrm{y}$.) and the rate of 2 to 10-14 m/m.y. through the Pliocene and Quaternary. Preservation is not as good as at Site 249. Especially in lower Miocene deposits, discoasters are dominant and coccolithophorids are partly dissolved. It can be inferred that the CCD was close to the deposition depth at that time.

Farther north (Site 241), the Neogene and Quaternary sequence, which accumulated on the fringe of the Kenyan continental margin, contains a significant amount of nannofossils. Through most of early and middle Miocene times, detrital deposits were interlayered with a calcareous sequence composed of about 40 to 60 percent nannofossils. Within the latest Miocene and Pliocene deposits, an important detrital clay fraction is mixed with nannofossils. Starting in the upper Pliocene to the Holocene, nannos are largely dominant $(50 \%-70 \%)$. The total sedimentation rate for the Quaternary is about $45 \mathrm{~m} / \mathrm{m}$.y. which implies an apparent nanno sedimentation rate of about 20 to 27 $\mathrm{m} / \mathrm{m}$.y. During the Miocene it approached only 12 to 14
SITE 241

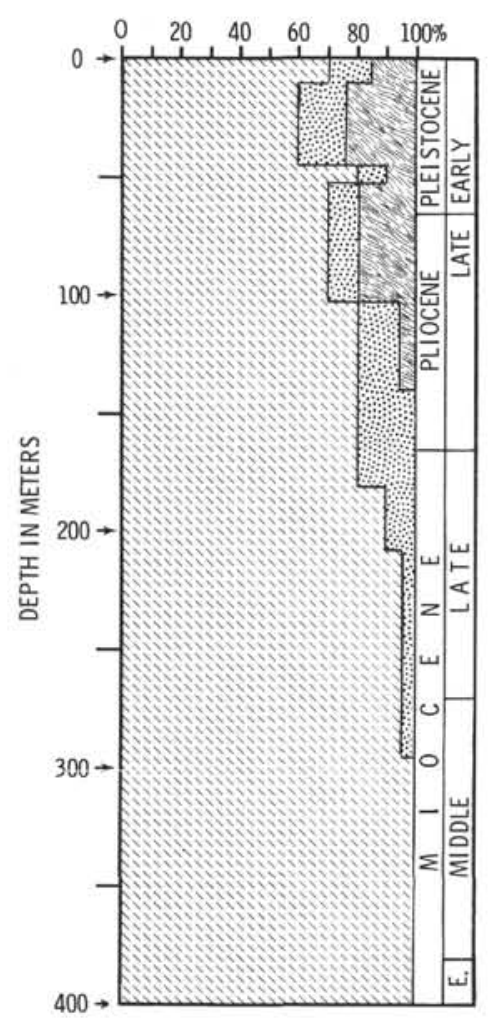

SITE 242

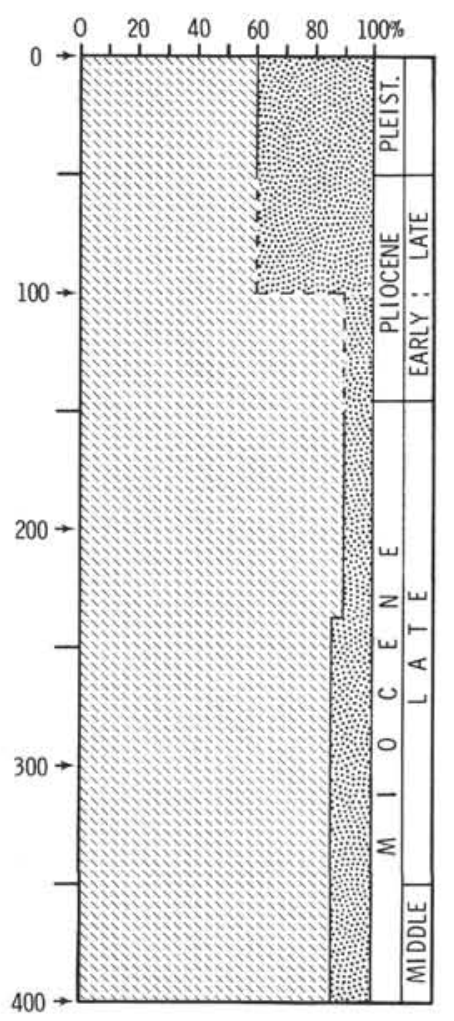

SITE 249

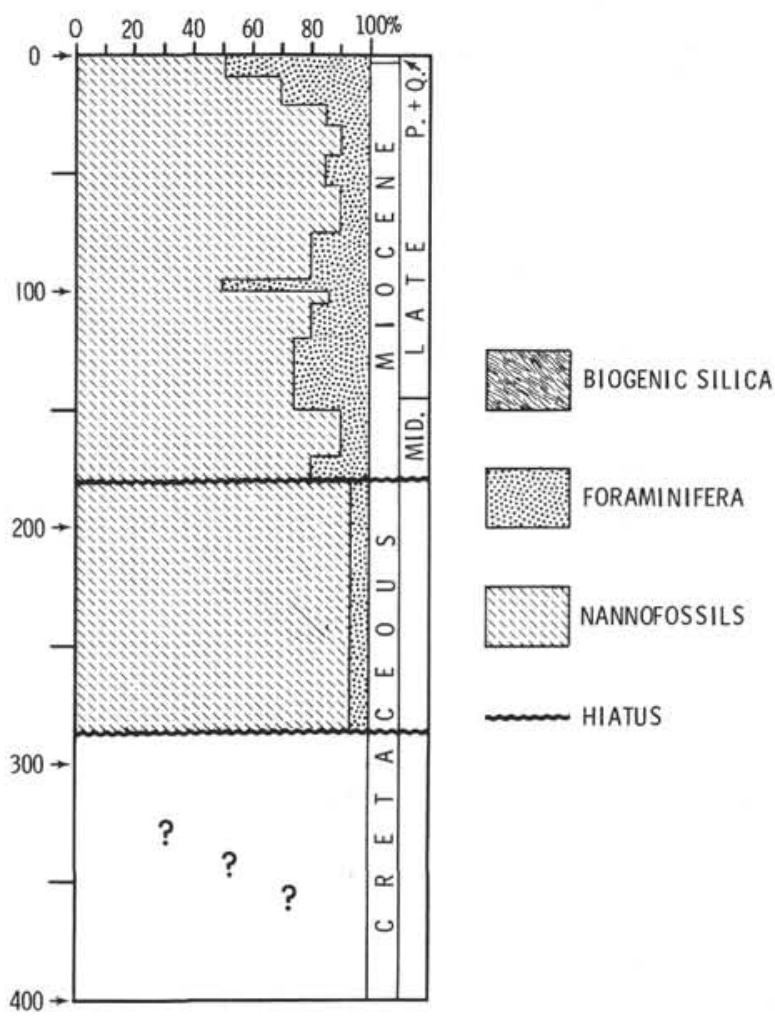

Figure 3. Relative percentages of three main pelagic constituents: biogenic silica, foraminifera, and nannofossils (semiquantitatively approximated from smear-slide analyses). 

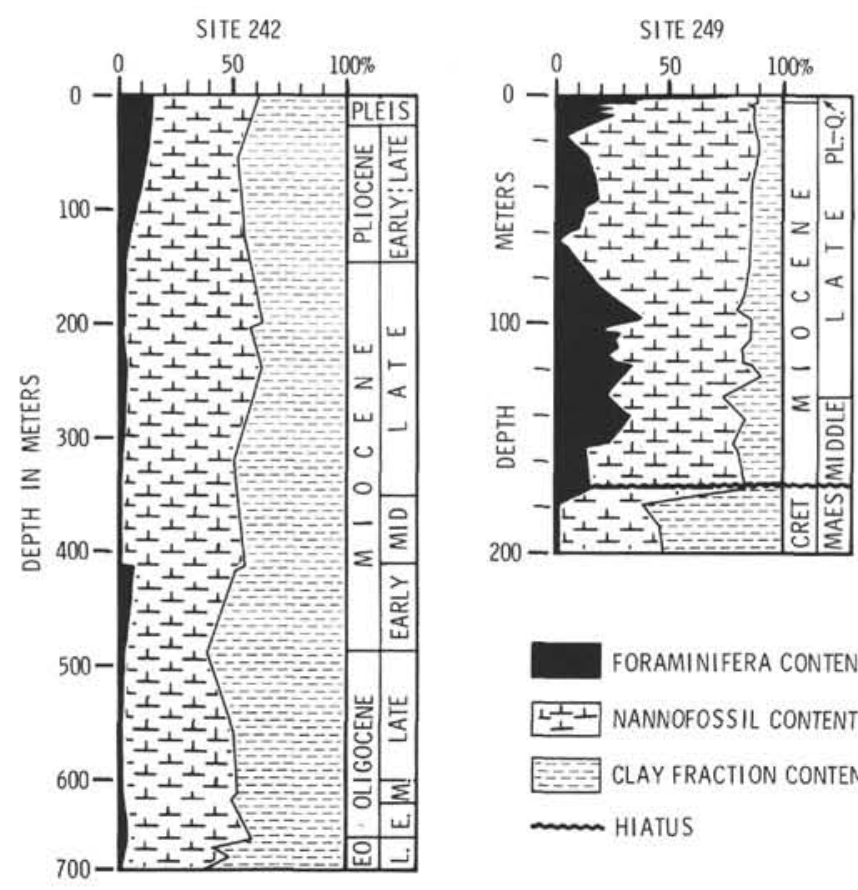

Figure 4. Main relative component variations through time at Sites 242 and 249 (from calcium carbonate and sieveremain analyses, see Tables 2 and 3).

$\mathrm{m} / \mathrm{m} . \mathrm{y}$. Mainly in Cores 13 and 14 (early middle Miocene), nanno content is far lower and species show some dissolution. Above this level the preservation is good.

In the Madagascar Basin, about 265 meters of more or less pure nannofossil accumulation is Paleocene and early Eocene in age. The late early Eocene nanno ooze is nearly pure, consisting of 80 to 85 percent nannofossils (Unit III). Below, the clay fraction increases downward, and micarb content is notable so that the underlying nannochalk includes only 60 to 70 percent nannofossils and in some places less. Estimations of the nannofossil rate of sedimentation range from 4 to $5 \mathrm{~m} / \mathrm{m}$.y. It rises considerably through early Eocene time and approaches 25 m/m.y., a very high value. In Core 7, Hole 245A, nannofossils are heavily calcified while at the boundary of lithologic Units I and II they are etched; above that level they disappear. No doubt the CCD reached the depositional depth by late Eocene time and has been staying either there or above until the present.

Nannofossils are also the main contributors to the middle and late Miocene lithologic sequence in the Mascarene Basin (Site 239) in which average nanno content ranges between 40 and 70 percent. Consequently, the total rate of sedimentation is highest $(22-24 \mathrm{~m} / \mathrm{m} . \mathrm{y}$.) through the late middle and late Miocene. Upper Cretaceous and lower Paleocene strata of nannofossils interbedded in the brown clay within the lowest sedimentary unit were very likely deposited close to the regional compensation depth because the nanno assemblage is very poor in species, most of which are dissolved. Even in the Miocene sediment, most of the coccolithophorids are dissolved, whereas the discoasters are still preserved. This indicates that the coccolith lysocline was near the depth of deposition. On the other hand, nannofossils of Pliocene to Pleistocene ages are abundant and well preserved. At other sites (e.g., 240, 246, and 248), it is possible to find thin layers of nannofossils but they are minor contributors.

\section{Foraminifera}

Two sites are especially remarkable owing to high concentrations of foraminifera in the sedimentary sequence: the Madagascar Ridge (Site 246) and the Mozambique Ridge (Site 249).

Smear-slide and sieve remain examinations establish that at Site 246 , foraminifera-mostly planktonic speciesrepresent from 50 to 80 percent of the sediment bulk, a surprisingly high amount. Lithologic Unit I is composed dominantly of sand-size foram ooze together with minor nanno foram ooze. It should be considered that foram concentrations such as these may be due to technical washing processes. In Core 4 , the mixed assemblage obviously resulted from the washing of the core out of the pipe, but the presence of semilithified foram chalk ooze (Core 3) demonstrates that the foram ooze is not necessarily a washed residue of a nanno-foram mixture. Natural winnowing by oceanic currents is more likely the real process of foraminifera enrichment. Through early Miocene to Quaternary times, foraminiferal tests are well preserved, which indicates that the foram lysocline was well below the depositional depth.

On the Mozambique Ridge (Site 249), the foraminifera content shows important changes through the thick Miocene and the thin Pliocene-Quaternary sequences. In the upper Miocene strata, foraminifera content approaches 40 percent, decreasing upward and then increasing again to about 70 to 80 percent at the top (Pliocene-Quaternary). The general tendency, as shown in Figure 4, is an increasing foraminifera content from the Miocene to the Quaternary. Below the great hiatus displayed at this site, the amount of foraminifera is nearly negligible, rarely higher than 5 percent (by weight). However, locally, foraminifera comprise as much as 20 percent.

The increasing foraminifera content through the Neogene is detected again in Sites 242 and 241 but is less obvious. On the Davie Ridge (Site 242), foraminifera are minor contributors and do not comprise more than 10 percent of the total pelagic deposit, i.e., about 5 percent of the sediment bulk (hemipelagite). An upward increase in foraminifera content is very clear at Site 242 (Figure 4) starting at the base of the Pliocene sequence. Curiously, preservation is variable and is very good at the top; signs of dissolution are visible at the bottom of Core 1 (Quaternary). Below Core 1, planktonic foraminifera are well preserved down to Core 3 where their amount diminishes and where fragmented species are partly dissolved. In Core 5 (late Miocene) the dissolution varies from sample to sample. Below, in Sample 6, CC, Globigerina nepenthes, a species resistant to dissolution, is dominant ( $50 \%$ of the foram assemblage). Dissolution seems heavy in the lower part of Core 7. In the upper Eocene and Oligocene sedimentary sequences, preservation is fairly good except that large species are often flattened by lithostatic pressure denoting here the beginning of diagenetic processes. 
TABLE 2

Approximate Calculations of Foraminifera, Nannofossil, and Clay Fraction Contents in the Upper Part of Site 249

\begin{tabular}{|c|c|c|c|c|c|c|c|}
\hline \multirow[b]{2}{*}{ Sample } & \multicolumn{3}{|c|}{ Foram Fraction (Weight \%) } & \multirow{2}{*}{$\begin{array}{c}\text { Clay } \\
+ \text { Nanno } \\
\text { Fraction } \\
(\%)\end{array}$} & \multirow{2}{*}{$\begin{array}{c}\text { Total } \\
\mathrm{CaCO}_{3} \\
(\%)\end{array}$} & \multirow{2}{*}{$\begin{array}{c}\text { Inferred } \\
\text { Nanno } \\
\text { Fraction } \\
(\%)\end{array}$} & \multirow{2}{*}{$\begin{array}{c}\text { Inferred } \\
\text { Clay } \\
\text { Fraction } \\
(\%)\end{array}$} \\
\hline & $\phi \geqslant 100 \mu$ & $50 \mu \leqslant \phi<100 \mu$ & Total & & & & \\
\hline $1-1,1 \mathrm{~cm}$ & 59 & 17 & 76 & 24 & 88 & 12 & 12 \\
\hline $1-1,48 \mathrm{~cm}$ & 21 & 15 & 36 & 64 & 89 & 63 & 11 \\
\hline $1-2,50-52 \mathrm{~cm}$ & 22 & 14 & 36 & 64 & 88 & 52 & 12 \\
\hline $1-3,130 \mathrm{~cm}$ & 5 & 9 & 14 & 86 & 86 & 72 & 14 \\
\hline $1-4,77 \mathrm{~cm}$ & 14 & 10 & 24 & 76 & 87 & 63 & 13 \\
\hline $14,131 \mathrm{~cm}$ & 12 & 10 & 22 & 78 & 87 & 65 & 13 \\
\hline $1-5,50 \mathrm{~cm}$ & 9 & 7 & 16 & 84 & 87 & 71 & 13 \\
\hline $1, \mathrm{CC}$ & 11 & 15 & 26 & 74 & 87 & 61 & 13 \\
\hline $2, \mathrm{CC}$ & 2 & 3 & 5 & 95 & 87 & 82 & 13 \\
\hline $3, \mathrm{CC}$ & 8 & 7 & 15 & 85 & 90 & 75 & 10 \\
\hline $4, \mathrm{CC}$ & 8 & 10 & 18 & 82 & 87 & 69 & 13 \\
\hline $5-3,81 \mathrm{~cm}$ & 13 & 6 & 19 & 81 & 86 & 67 & 14 \\
\hline $6-1,81 \mathrm{~cm}$ & 8 & 6 & 14 & 86 & 85 & 71 & 15 \\
\hline $6, \mathrm{CC}$ & 5 & 6 & 11 & 89 & 86 & 75 & 14 \\
\hline $7-2,79 \mathrm{~cm}$ & 4 & 6 & 10 & 90 & 86 & 76 & 14 \\
\hline $7, \mathrm{CC}$ & 1.5 & 0.5 & 2.0 & 98 & 86 & 84 & 14 \\
\hline $8-1,130 \mathrm{~cm}$ & 1 & & 6 & 94 & 86 & 80 & 14 \\
\hline $10-1,101 \mathrm{~cm}$ & 11 & 10 & 21 & 79 & 83 & 62 & 17 \\
\hline $10, \mathrm{CC}$ & 23 & 12 & 35 & 65 & 80 & 45 & 20 \\
\hline $11-2,61 \mathrm{~cm}$ & 30 & 9 & 39 & 61 & 85 & 46 & 15 \\
\hline $11-2,75 \mathrm{~cm}$ & 17 & 11 & 28 & 72 & 87 & 59 & 13 \\
\hline $11, \mathrm{CC}$ & 12 & 9 & 21 & 79 & 86 & 65 & 14 \\
\hline $12-1,81 \mathrm{~cm}$ & 20 & 9 & 29 & 71 & 86 & 57 & 14 \\
\hline $12-3,104 \mathrm{~cm}$ & 13 & 13 & 26 & 74 & 86 & 60 & 14 \\
\hline $12-5,110 \mathrm{~cm}$ & 14 & 12 & 28 & 72 & 82 & 54 & 18 \\
\hline $13-1,97 \mathrm{~cm}$ & 11 & 12 & 23 & 77 & 83 & 60 & 17 \\
\hline $13-5,30 \mathrm{~cm}$ & 19 & 8 & 27 & 73 & 83 & 56 & 17 \\
\hline $13-5,100 \mathrm{~cm}$ & 22 & 12 & 34 & 66 & 84 & 50 & 16 \\
\hline $13, \mathrm{CC}$ & 14 & 16 & 30 & 70 & 85 & 55 & 15 \\
\hline $14-1,115 \mathrm{~cm}$ & 13 & 10 & 23 & 77 & 73 & 60 & 27 \\
\hline $14-6,130 \mathrm{~cm}$ & 19 & 14 & 33 & 67 & 83 & 50 & 17 \\
\hline $15-1,64 \mathrm{~cm}$ & 4 & 19 & 23 & 77 & 78 & 55 & 22 \\
\hline $15-3,100 \mathrm{~cm}$ & 6 & 7 & 13 & 87 & 80 & 67 & 20 \\
\hline $16-2,34 \mathrm{~cm}$ & 7 & 8 & 15 & 85 & 84 & 69 & 16 \\
\hline $16, \mathrm{CC}$ & 2 & 1 & 3 & 97 & 38 & 35 & 62 \\
\hline $17, \mathrm{CC}$ & 0.5 & 0.5 & 1 & 99 & 47 & 46 & 53 \\
\hline
\end{tabular}

aEach dried and weighed sample was dispersed in water using weak ultrasource vibrations and sieved. The $100 \mu$ sieve remains are mostly foraminifera (determined by microscope), while $50 \mu$ sieve remains are mainly foraminifera fragments. Residue (fraction with particle diameters less than $50 \mu$ ) is considered to be composed mainly of nannofossils, clay minerals, and rare detrital, silt-sized particles (smear-slide estimations). All fractions obtained were dried and weighed. Given the total calcium carbonate and the approximate foraminifera content, it is possible to infer nannofossil content and clayfine silt fraction percentages. A similar reasoning and method was applied to Site 242 material (Table 3).

At Site 241, foraminifera are minor contributors but still are present in noticeable amounts $(5 \%-20 \%$ as estimated from smear-slide analysis) in the late Miocene and Pliocene-Quaternary deposits. It appears that the total amount of foraminifera is negligible below these levels because of strong dissolution. Zobel (see site reports) noticed extreme calcium carbonate dissolution in Cores 12 and 13. From Core 7 (late Pliocene), dissolution increases with depth, affecting Core 8 to Core 15 (mainly middle Miocene). In comparing the preservation of nannofossils 
TABLE 3

Approximate Calculations of Foraminifera, Nannofossil, and Clay Fraction Contents of Site 242 Stratigraphic Column

\begin{tabular}{|c|c|c|c|c|c|c|c|}
\hline \multirow[b]{2}{*}{ Sample } & \multicolumn{3}{|c|}{ Foram Fraction (Weight \%) } & \multirow{2}{*}{$\begin{array}{c}\text { Clay } \\
+ \text { Nanno } \\
\text { Fraction } \\
\quad(\%)\end{array}$} & \multirow{2}{*}{$\begin{array}{c}\text { Total } \\
\mathrm{CaCO}_{3} \\
(\%)\end{array}$} & \multirow{2}{*}{$\begin{array}{l}\text { Inferred } \\
\text { Nanno } \\
\text { Fraction } \\
(\%)\end{array}$} & \multirow{2}{*}{$\begin{array}{c}\text { Inferred } \\
\text { Clay } \\
\text { Fraction } \\
(\%)\end{array}$} \\
\hline & $\phi \geqslant 100 \mu$ & $50 \mu \leqslant \phi<100 \mu$ & Total & & & & \\
\hline $1, \mathrm{CC}$ & 10.0 & 7.5 & 17.5 & 82.5 & 60.5 & 43.0 & 39.5 \\
\hline $2, \mathrm{CC}$ & 8.0 & 3.0 & 11.0 & 89.0 & 51.0 & 40.0 & 49.0 \\
\hline $3, \mathrm{CC}$ & 1.8 & 1.7 & 3.5 & 96.5 & 54.0 & 51.5 & 45.0 \\
\hline 4-6 & 0.5 & 1.5 & 2.0 & 98.0 & 64.0 & 62.0 & 36.0 \\
\hline $4, \mathrm{CC}$ & 0.5 & 1.0 & 1.5 & 98.5 & 58.0 & 56.5 & 42.0 \\
\hline $5, \mathrm{CC}$ & 0.7 & 2.4 & 3.1 & 97.0 & 62.5 & 59.5 & 38.5 \\
\hline $6, \mathrm{CC}$ & 0.1 & 0.4 & 0.5 & 99.5 & 44.5 & 44.0 & 55.5 \\
\hline $7-6$ & 0.3 & 0.9 & 1.2 & 98.5 & 44.5 & 43.3 & 45.2 \\
\hline $7, \mathrm{CC}$ & 3.5 & 3.0 & 5.5 & 93.5 & 50.7 & 44.2 & 49.3 \\
\hline $8, \mathrm{CC}$ & 0.2 & 0.6 & 0.8 & 99.0 & 38.0 & 37.0 & 62.0 \\
\hline $9, \mathrm{CC}$ & 0.1 & 1.0 & 1.1 & 99.0 & 52.0 & 51.0 & 48.0 \\
\hline $10, \mathrm{CC}$ & 0.1 & 0.4 & 0.5 & 99.5 & 51.0 & 50.5 & 49.0 \\
\hline $11, \mathrm{CC}$ & 0.5 & 0.5 & 1.0 & 99.0 & 49.0 & 48.0 & 51.0 \\
\hline $13, \mathrm{CC}$ & 0.2 & 1.5 & 1.7 & 98.0 & 54.0 & 52.0 & 46.0 \\
\hline $14, \mathrm{CC}$ & 0.6 & 1.6 & 2.2 & 98.0 & 58.0 & 55.8 & 42.2 \\
\hline $16, \mathrm{CC}$ & 1.0 & 1.4 & 1.6 & 98.4 & 39.5 & 37.9 & 60.5 \\
\hline $17, \mathrm{CC}$ & 0.1 & 0.4 & 0.5 & 99.5 & 47.5 & 47.0 & 52.5 \\
\hline $18, \mathrm{CC}$ & 0.2 & 0.3 & 0.5 & 99.5 & 40.0 & 39.5 & 60.0 \\
\hline
\end{tabular}

and foraminifera, it is obvious that the foram lysocline is quite different from the nanno lysocline and must have remained well above the CCD.

Black ferromanganoan nanno chalk of Site 245 , which rests upon the basalt, contains a significant amount of foraminifera (about $1 \%-5 \%$ ). Elsewhere, foraminifera contents are minor and their contribution is quite restricted.

\section{Siliceous Components}

The presence of a few radiolarians is known in the Late Cretaceous clayey nanno ooze of Site 239 and sponge spicules appear within the clay/carbonate-rich nanno ooze of middle Miocene age; spicules increase upward through the middle and late Miocene and reach 15 percent of the total bulk of sediment in Core 6. Radiolarians in low quantities accompany the sponge spicules. Diatoms were noticed in the faunal residue of Core 4 and in smear slides of Cores 2 and 3 (Pliocene). Through late late Miocene time, sponge spicule content clearly decreases and, as for radiolarians, is restricted to only traces within the Plio-Pleistocene nanno ooze.

Rad ooze interlayered with nanno-bearing silt-rich clay characterizes the uppermost part of the sedimentary column (Quaternary) in the Somali Basin (Site 240). In Core 1 , radiolarian content is 20 to 45 percent. Diatoms are present in minor amounts $(2 \%-10 \%)$.

Radiolarians in trace amounts occur in the upper Miocene sediment of Site 241 together with rare sponge spicules. These radiolarians of ten are broken and pyritized. Radiolarian and diatom content increases in the Pliocene and Pleistocene strata (Figure 4). The Quaternary sequence at Site 241 is mostly a rad/diatom/foram-rich or -bearing nanno ooze. The average combined content in radiolarians and diatoms is about 5 percent.

On Davie Ridge (Site 242), siliceous pelagic components include radiolarians and sponge spicules in trace amounts. They are localized in the Quaternary deposits.

Radiolarians are relatively abundant in the brown clay (Unit III) and the volcanic silty clay (Unit II) at Site 248 in the Mozambique Basin. Apparently, they were deposited in Paleocene and early Eocene times. They are absent in the overlying Miocene deposits.

A few radiolarians and sponge spicules were observed in the Neocomian strata of the Mozambique Ridge (Site 249). Their amount markedly increases in the upper Albian-lower Cenomanian sequence and then they subsequently disappear. Trace amounts of radiolarians also were observed at Site 245 in sieve remains, but are very minor and restricted to certain levels.

\section{Other Biogenous Components}

Tunicate spicules were observed at Site 239 (Cores 1, 2, and 3 ) in fairly high amounts (5\%). These spicules were found in layers that are out of the normal Tunicate biotope. Moreover, bearing in mind that those spicules are aragonitic, they should have been dissolved (depth of about $4970 \mathrm{~m}$ ). Consequently, those spicules are very likely redeposited, perhaps from the upper continental slope (Madagascar?).

Small yellow spheres $(\sim 200 \mu)$, hardly soluble in $\mathrm{HC1}$ (dolomite?), were found at Site 239 in Cores 11 and 13. They are thought to be of biogenous origin (recrystallized pellets?). Some ostracods are disseminated here and there, at the bottom of Hole 249 for instance, but occur only in trace amounts. 


\section{LECLAIRE}

Fish remains (teeth and bone fragments) were commonly found in brown clay at Sites 245 and 239 and also in the Eocene silty clay of the Somalian continental slope (Site 241). Such remains were noticed also in the brown clay resting upon basalt at Site 248 .

Carbon-carbonate analyses (Girdley, this volume) show fairly high contents of organic matter in Neocomian and Albian-Cenomanian strata on the Mozambique Ridge. Throughout 120 meters of claystone and volcanic siltstone resting upon the basaltic rocks, organic carbon contents average about 1 percent. Peak values of 1.6 percent are common. The two sites at low latitudes $(240,241)$ display a sedimentary column that has organic carbon in notable amounts (from $0.3 \%-0.6 \%$ with a peak value of $2 \%$ at Site 241). Some amounts as high as 2 percent typify the flysch sequence of Site 241 which was emplaced mainly in the Late Cretaceous. Origin of this organic matter is possibly terrigenous. Apart from these deposits, it appears that organic carbon content increases progressively upwards from late Miocene to Pleistocene through the predominantly pelagic deposit of the uppermost part of the sedimentary column at Site 241. This observation is supported by organic carbon analysis of Site 240 sediments in which organic carbon content increases from 0.1 to 0.6 percent from the upper Miocene to Pleistocene.

\section{Halmeic Components}

The most common halmeic components throughout the stratigraphic columns cored in the central western Indian Ocean are zeolites, pyrite, and $\mathrm{Mn} / \mathrm{Fe}$ oxides.

\section{Zeolites}

Two major zeolite minerals were found in Leg 25 sediments using the methods of smear-slide investigation and X-ray diffraction analysis. There is a discrepancy between the results obtained by these methods; the clinoptilolite, seen as euhedral to subhedral laths in trace amounts, is not always confirmed by subsequent X-ray analysis. Such discrepancy has been previously reported by Berger and von Rad (1972) who state that zeolites must occur in significant amounts in order to be identified by X-ray diffraction.

Clinoptilolite was observed (by petrographic microscope) in the late Cenozoic brown clay of Site 245 and was also identified in Eocene nanno ooze (subunit IIIA) where 2 to 3 percent occurs (Cook and Zemmels, this volume). Clinoptilolite is also an important component in the volcanic sands (Cores 10-12) at Site 246 on the Madagascar Ridge and was detected in a volcanic clay layer (Cores 12 , 13) at Site 248. Abundant clinoptilolite helps characterize the third lithologic unit cored at Site 249. Amounts higher than 10 percent are relatively frequent at this site reaching 38 percent of the $2-20 \mu$ fraction in some layers.

Phillipsite is poorly distributed in sediment of the central western Indian Ocean. This zeolite was identified in the Mascarene Basin (Site 239), in lithologic Unit I, where it comprises from 6 to 15 percent of the $2-20 \mu$ fraction. On Madagascar Ridge (Site 246), phillipsite is associated in high amounts (10 percent) with clinoptilolite, which together form zeolite-rich volcanic sands.

\section{Fe-Mn Oxides}

Two types of Fe-Mn oxides are distinguished by the nature of sediments in which they are found. The first type generally appears as nodules, micronodules, or coatings in pelagic deposits that rest well above the basaltic "basement." An example of this type occurs in lithologic Unit III of Site 242 where an iron manganese-rich chalk occurs in burrows in which oxides either coat foraminifera tests or are finely disseminated as matrix. Another example is furnished at Holes 245 and 245A where brown clay displays many black streaks, blebs, and patches which are believed to be produced by manganese microaggregates. In Hole 245A, Core 2, Section 6, a small nodule is $1 \mathrm{~cm}$ in diameter. Several similar nodules were seen in the brown clays of Site 239 (in the upper part of Core 15). All in all, however, manganese nodules seem to be very rare throughout the Leg 25 sediment columns.

The second type of Fe-Mn oxide is exhibited in the basal part of sedimentary columns resting directly upon basaltic "basement." Amorphous agglomerates of these oxides are finely disseminated in the sediment. A good example is the ferromanganoan nanno chalk of the Madagascar Basin (Site 245 ). Here, Fe-Mn in the matrix gives a brownish-black hue to the deposit. Another example is provided by the red and blackish-red laminations of lithologic Unit III in Hole 248 (Paleocene brown clay and brown silty-bearing clay). Iron-manganese-rich sediments at Site 245 are more extensively studied in a special chapter (Warner and Gieskes, this volume).

\section{Pyrite}

Pyrite occurs in many different forms throughout the sedimentary columns: as microaggregates and irregular grains (recorded as opaques in smear-slide analyses); as spherulites with subhedral crystals; as replacement of sponge spicules and radiolarians; and as fillings of burrows and foraminifera tests. Some large burrow fillings, several centimeters long, were found at Site 242 (Core 2). These fillings, under scanning electron microscope investigations, exhibit a peculiar structure (Plate 4). First, the filling is not completely achieved and an axial void is left. The first layer of pyrite deposited directly upon the wall of the burrow is composed of coalescing microaggregates, whereas pyrite carpeting the inside of the burrow filling shows subhedral to euhedral crystal structure (Plate 4, Figures 3, 4).

Pyrite occurs as sponge spicule and radiolarian replacements in the white clay-rich nanno ooze of late middle and late Miocene age in the Mascarene Basin (Site 239). Fillings of foraminifera and individual aggregates constitute trace abundances throughout the upper part of the sedimentary column, i.e., from middle Miocene up to Quaternary near the East African continental margin (Site 241). Pyrite is mainly concentrated in the $2-10 \mu$ fraction in amounts higher than 2 percent. Other notable occurrences of pyrite in Hole 241 are located in Cores 27 (the Cretaceous flysch sequence). Throughout the upper Miocene and Quaternary deposits of the Davie Ridge (Site 242), trace abundances, mainly of pyrite in the form of burrow casts, were observed. Abundant black spots and 
streaks of pyrite are disseminated in lithologic Unit I at this site. The high concentrations of pyrite in Cretaceous volcanic siltstone and claystone measured at Site 249 are striking. In effect, peak peak values as high as 7 percent were obtained. However, the presence of pyrite in such high amounts was more or less to be expected because of the high concentration in organic matter.

\section{Terrigenous and Hemihalmeic Components}

Table 4 shows that the minerals quartz, K-feldspar, plagioclase, and kaolinite, which are mostly of terrigenous origin, constitute the major fraction of "pelagic" brown clays. If clay minerals also are terrigenous, those deposits could be considered as detrital. However, because of their very low rate of sedimentation (less than $5 \mathrm{~m} / \mathrm{m}$.y.), this kind of sediment is referred to as a pure pelagic deposit. Moreover, they generally contain an important halmeic fraction with zeolites and varieties of oxides.

A question which remains, asks if all the clay minerals are of terrigenous origin. First, the origin of montmorillonite is questionable. This clay species is abundantly distributed throughout the lithologic sequences, especially when volcanic influxes are present. It appears very often as a product of devitrification of volcanic glass. Consequently, it is not unreasonable to expect an important part of this montmorillonitic fraction not to be land derived but rather pelagic, resulting from the interaction between oceanic waters and volcanic products. Palygorskite may be formed from vitreous ash via palagonite and montmorillonite by precipitation from Mg-rich interstitial solutions or under hydrothermal influences (Berger and von Rad, 1972) with silica being derived from altered silicic ash (Calvert, 1971). Furthermore, according to MacKenzie and Garrels (1966), authigenesis of chlorite and especially of illite seems possible in oceanic waters. If land-derived clay minerals are not diagenetically modified to a large extent when entering oceanic waters, Griffin and Goldberg (1961) suggest that degraded illite and chlorite may take up $\mathrm{K}^{+}$and $\mathrm{Mg}^{2+}$ and change to more crystalline minerals. Then, it appears that the whole clay fraction cannot be considered only as a land-derived product. Part is certainly terrigenous, another part is halmeic; proportions of each part generally are unknown. Finally, the clay mineral fraction is a mixture of terrigenous and halmeic products and is considered to be an hemihalmeic component.

\section{Volcanogenic Components}

Palagonite was identified in Cores 8 and 9 of Hole 239 and in subunit IIA together with devitrified volcanic ash (believed to be an important contributor to brown clay resting upon the volcanic basement).

Volcanic glass occurs in trace amounts throughout the Neogene hemipelagic sequence off the East African continental slope, and one devitrified volcanic ash bed was seen in Sample 241-7, CC.

In the Madagascar Basin, numerous devitrified volcanic ash layers occur in the nanno chalk sequence. In some of them, remains and outlines of partly dissolved volcanic glass fragments were observed.
TABLE 4

Mineral Contents (percent) in Selected Brown Clays (from DSDP X-ray Analysis)

\begin{tabular}{lccc}
\hline \multicolumn{1}{c}{ Minerals } & Site $245^{\mathrm{a}}$ & Site $245 \mathrm{~A}^{\mathrm{b}}$ & Site $239^{\mathrm{c}}$ \\
\hline Quartz & 26.0 & 20.0 & 17.1 \\
K-Feldspar & 16.9 & 3.5 & 96.4 \\
Plagioclase & 18.6 & 17.0 & 8.2 \\
Kaolinite & 7.2 & 6.4 & 15.1 \\
Mica & 19.3 & 18.4 & 9.6 \\
Palygorskite & - & 26.3 & - \\
Gibbsite & 1.6 & 1.0 & - \\
Montmorillonite & 10.4 & 7.5 & 23.7 \\
\hline
\end{tabular}

a Depth $=8.2$ meters.

b Depth $=16.8$ meters.

$\mathrm{c}_{\text {Depth }}=159.1$ meters

Volcanic components are abundant in the basal lithologic sequence of Site 246. The volcanic breccia and volcanogenic reworked material that characterize this sequence cannot be considered as a pelagic deposit. Similarly, the origin of gray and olive-black volcanic claystones which form the lower part of the sedimentary column cored on the Mozambique Ridge (Site 249) is questionable. Because of the predominant quantity of pyroclastic material, these deposits are referred to as volcanogenic deposits (Vallier, this volume).

\section{Preliminary Conclusions on Distribution of Pelagic Sediments}

\section{Pelagic Sediments Compared with Terrigenous and Volcanic Sediments Through Time}

It is striking to find out from the foregoing discussion that all Leg 25 sedimentary columns recovered are capped predominantly with relatively pure pelagic deposits. This is independent of site location.

It appears that throughout late Cenozoic time, pelagic supplies, when compared to terrigenous ones, progressively increase or definitely dominate, while high sedimentation rates of biogenous deposits were reached. In the Somali Basin, where detrital and terrigenous sediments are dominant during most of the Late Cretaceous-Paleogene interval, pelagic input occurs through Quaternary time at Site 240 and pelagic sedimentation products are abundant from early Miocene to Quaternary at Site 241. Even in the Mozambique Basin where the Zambezi Canyon debouches abundant detrital sediments, nanno ooze occurs in the Plio-Pleistocene layers.

Basaltic rocks were reached five times; except at Site 249 , a relatively thick pelagic sedimentary sequence was observed resting directly upon or very close to the basaltic "basement."

Both the Mozambique and Madagascar ridges (Sites 249 and 246) are capped with biogenous deposits which overlie volcanoclastic sediments.

Hiatuses mainly occur in pelagic deposits. Either they cut through a predominantly pelagic sedimentary sequence as at Site 245 or they separate two different lithologies, one 
of which is a pelagic deposit (Sites 241, 246, 249). Consequently, it can be inferred that hiatuses are associated, at least in part, with great changes in sedimentation patterns.

\section{Variation of Biogenic Supplies with Time}

When compared to nannofossil contents, foraminifera clearly increase through Cenozoic time and especially through the late Miocene, Pliocene, and Quaternary. This phenomenon might be in connection with the increased pelagic sedimentation during these same times. Morover, siliceous biogenous components, when present in Cenozoic deposits (Sites 239, 240, 241, and 242), occur chiefly in upper Miocene sequences and then their content increases through Pliocene time (except at Site 239). Notable amounts of sponge spicules and radiolarians were found within the Lower Cretaceous deposits at Site 249, but they definitely disappear through middle Cretaceous time and never occur again in the overlying Cenozoic deposits.

Similarily, contents in organic matter, when present in Tertiary deposits, increase through late Cenozoic time (Sites 240 and 241).

Consequently, the first preliminary conclusion that can be safely drawn is the apparent increasing productivity of central western Indian Ocean waters through late Cenozoic time.

\section{MAIN PELAGIC FACIES-DEPOSITIONAL ENVIRONMENTS}

\section{Nanno Ooze and Chalk}

\section{Paleogene Nanno Ooze and Chalk of Madagascar Basin}

This calcareous facies, 264 meters thick, constitutes the main sedimentary sequence of Site 245 (see Chapter 7). The average sedimentation rate mostly ranges from 17 to $20 \mathrm{~m} / \mathrm{m} . \mathrm{y}$. but reaches 30 to $35 \mathrm{~m} / \mathrm{m} . \mathrm{y}$. in the lower Eocene strata. Average as well as peak values are high compared to other sedimentation rates in regions of reputed high productivity such as equatorial Pacific belt where 15 to $17 \mathrm{~m} / \mathrm{m}$.y. were measured for Miocene deposits (Tracey, Sutton, et al., 1970).

X-ray bulk analysis, calcium carbonate content, and $\mathrm{HCl}$ residue determinations point to a very low proportion of quartz and K-feldspar, i.e., to a very weak terrigenous influx. The main contributor besides nannofossils and foraminifera is undoubtedly montmorillonite. As discussed previously, partly dissolved volcanic glass and shard outlines within montmorillonite beds testify in favor of a volcanic origin for this clay mineral. Other volcanic influence is suggested by the presence of clinoptilolite for, according to Biscaye (1965), this mineral is considered to be a volcanic associated zeolite. Today, kaolinite and gibbsite (from Madagascar laterite) constitute only a small absolute percentage of the total sediment around Madagascar. The principal mineral is montmorillonite which is believed to be the result of the in situ formation from volcanic products in the Madagascar and Mascarene basins. It is not unreasonable to think that plagioclase as well might be a volcanic derivative. Consequently, it can be assumed that either the erosional activity was very weak in Madagascar during
Paleocene and early Eocene time, the site was very far from Madagascar, or the site was isolated from terrigenous sedimentation.

Therefore, pelagic sedimentation, mostly biogenic, was largely predominant at this site. Because of the high rate of sedimentation, one could expect that the depositional area was in a high productivity zone such as an equatorial divergence during the early Cenozoic. Hays, Saito, et al. (1969); Tracey, Sutton, et al. (1971); van Andel, Heath, et al. (1971); Heezen, MacGregor, et al. (1972); and many others extensively studied deposits below the Pacific equatorial belt and Olausson et al. (1971) described the sedimentation below the Somali current. An important characteristic of the sedimentation in high productivity zones can be inferred from those works. Generally, in these zones, pelagic deposits are not pure nanno ooze but a mixture of nannofossils and abundant biogenic silica (diatoms, radiolarians) with, in addition, abundant (sometimes predominant) foraminifera. This is quite different at Site 245 even though the basal part of the sedimentary column bears a certain quantity of foraminifera (1\%-5\%). Possibly foraminifera and radiolarians might have been dissolved although signs of foraminifera dissolution were not clearly seen. Generally, planktonic foraminifera, when present, are diversified and in an excellent state of preservation; some recrystallized shells and nannofossils, however, were seen in the lower middle Eocene ooze. Moreover, dissolution below high productivity zone occurs at great depths because the foram lysocline and the CCD are depressed (more than $5000 \mathrm{~m}$ is common), but Site 245 area deepened only from 2700 to 4000 meters which is not deep enough for abundant dissolution. Consequently, the absence or rare occurrences of foraminifera and radiolarians at Site 245 can hardly be ascribed to dissolution. More likely, this phenomenon might reflect sedimentation below a rather low productivity water mass.

As suggested by Olausson (1961), coccolithophorids dominate in low productivity areas while their relative importance, on the whole, increases when going from a more fertile to a less fertile region. This idea is supported by Lisitzin (1971a) and Uschakova (1971) who conclude that areas of purest carbonate accumulation are not in the greatest production zones. Thus, according to Berger and von Rad (1972), the high nannofossil proportions associated with low foraminiferal content can be considered as characteristic of deposits below waters of rather low fertility. This sort of plankton impoverished waters is believed to be located in the "arid" zones of the oceans' central water masses which are surrounded by current gyrals (Bé and Tolderlund, 1971), e.g., the central water masses of the South Atlantic. Usually, those waters are found today between $15^{\circ}$ to $35^{\circ}$ latitude and roughly correspond to tropical-subtropical belts.

High rates of sedimentation and the associated very low foram/nannofossil ratio might indicate sorting by bottom currents. The great mobility of nannofossils compared to foraminifera is indicated, for instance, by the frequent contamination of young deposits by older nannofossils. It is very likely that the abnormal rate of sedimentation measured at Site 245 for the lower Eocene ooze results 
from the reworking of older nannofossils. Such a redeposition would be greatly favored by a surrounding rough topography which is characterized by steep slopes with resultant unstable deposits.

Thus, it can be tentatively concluded that nanno ooze and chalk of Site 245 were deposited in a somewhat isolated basin below oceanic waters very similar to present tropical water masses. Isolation of the site area is further supported by results from foraminifera studies which point to a special environment with regard to the well-known equatorial to tropical faunal assemblages and to classic regions such as the Caribbean and Mediterranean seas and New Zealand.

Nanno ooze deposition ended abruptly in Core 245-3 and is replaced by brown clay mixed with silty clay and interlayered nanno ooze. Most of the younger lithologic sequence displays some weak turbidite influences. Abundances of land-derived materials such as quartz, K-feldspar, kaolinite, chlorite, hematite, and epidote indicate considerable terrigenous influxes. Most of the interlayered nanno ooze beds are redeposited as evidence by reworked benthonic foraminifera assemblages which comprise mixed forms coming from medium shelf depths and displaced into a bathyal association. Similar deposits of pelagic turbidites close to or below the CCD has been noted by Bezrukov (1971) in the Indian Ocean. Studying Quaternary deposits, he observed, at the foot of submarine ridges, carbonate sand and ooze down to depths of 5500-5600 meters, i.e., considerably deeper than the critical depth (CCD).

In summary, by middle Eocene time, the Site 245 area was apparently deepening faster than before and subsequently reached the CCD. At the same time, the physiographic environment of Site 245 changed. The heretofore closed area was opened and subsequently invaded by detrital land-derived materials while faunal assemblages were renewed.

\section{Other Paleogene Nanno Ooze and Chalk}

In the Mascarene Basin, some clayey nanno ooze or nanno clay layers were found at the bottom of Site 239, resting directly on the basaltic "basement." These minor nannofossil facies, among the major facies of brown clay, accumulated in Late Cretaceous and early Paleocene times. They contain a peculiar foraminiferal assemblage which has benthic species belonging to the middle or lower part of continental slopes while pelagic forms are absent. It seems very likely that such layers were deposited from turbidity currents.

Lower Paleocene nanno ooze displays partly dissolved nannofossils and chiefly agglutinant benthic foraminifera. The poverty of this microfauna suggests a bathyal depth which was below the foram lysocline and close to the CCD. Compared to the lower Cenozoic sediment sequence of the Madagascar Basin (Site 245) which is typical of sedimentation over a spreading ridge crest and flank, deposits resting upon the basaltic "basement" at Site 239 appear to be somewhat different.

In the Somali Basin, at Site 240, the basal lithologic sequence includes minor nanno ooze and calcareous facies formed during early Eocene and contain mainly displaced fauna. These layers are believed to be mostly pelagic turbidites. However, fauna are rich, and well-preserved planktonic assemblages generally contain guide species. Benthonic species show little diversification and major species apparently represent an impoverished bathyal assemblage.

\section{Miocene Nanno Ooze of Mozambique Ridge}

The composition of nanno ooze at Site 249 is illustrated in Figures 2 and 4 . The rate of sedimentation during late Miocene was about $25 \mathrm{~m} / \mathrm{m}$.y., which is comparable to sedimentation in the Madagascar Basin through the Eocene. The very minor noncalcareous fraction is mainly clay minerals (montmorillonite). It appears that terrigenous sedimentation was very weak on this ridge through late Miocene. Consequently, consideration of the sedimentation rate, foraminifera/nannofossils ratio, and foraminifera assemblages yield significant data about paleoenvironmental conditions.

First the occurrences of all stratigraphically important species of Miocene planktonic foraminifera and nannofossils indicate that a general worldwide distribution of water masses was present. Faunal assemblage variations seem to be related only to glacial-induced climatic fluctuations which began as early as early Miocene (Hayes, Frakes, et al., 1973). High content of foraminifera may indicate both the presence of a high productivity zone and the winnowing of nannofossils by deep-sea currents. However, the high rate of sedimentation implies rather high productivity conditions in the overlying water. Presently, higher foraminiferal abundances are found in the major current gyrals that surround the central water masses discussed previously. As an example, Olausson et al. (1971) points to a close connection between Somali Current movements and foraminifera concentrations through late Pleistocene in sediments of the Somali Basin. They concluded that foram ooze beds are related to the occurrence of high nutrient levels in the overlying water masses. One can assume that similar conditions were acting over the Mozambique Ridge by late Miocene times.

Figure 3 shows two striking facts: (1) foraminifera content is highest in middle Miocene deposits where the sedimentation rate is lowest $(10 \mathrm{~m} / \mathrm{m} . \mathrm{y}$.) and (2) foraminifera content is the lowest in late Miocene ooze where the sedimentation rate is the highest $(25 \mathrm{~m} / \mathrm{m} . \mathrm{y}$.). These sharp changes in the foraminifera/nannofossil ratio through middle and late Miocene strongly suggest the effects of current action. It seems very likely that in the first case, currents winnowed out the nannofossils, thereby concentrating foraminifera, whereas in the second case, there was redeposition of previously resuspended nannofossils. There currents were rather weak but presumably became stronger by Pliocene-Quaternary times which might account for the condensed Pliocene-Quaternary section at the top of the sedimentary column of Site 249. Currents are probably still acting, since, according to Saito and Fray (1964), two cores raised from the Mozambique Ridge contained a mixed assemblage including Late Cretaceous, Eocene, Miocene, and Recent foraminifera. They believe that this sediment was derived from submarine erosion of sediments cropping out at higher elevations on the 
Mozambique Ridge. New data from Harris (1972) strongly support this point and will be discussed later.

\section{Late Cenozoic Foram Sand of Madagascar Ridge}

Despite the fact that intermittent coring and poor recovery of the upper part of the sedimentary column at Site 246 did not allow proper studies of the sediment composition, paleoenvironmental reconstruction can be attempted. Conspicuous at this site is the great quantity of planktonic foraminifera which constitutes more than 60 percent of the sediment bulk on the average. It is possible that technical difficulties encountered while drilling this deposit came from the sandy texture of the sediment and the washing may have contributed to further enrichment in foraminifera; however, it seems very likely that the foram sand is the result of original concentration during sedimentation. Approximate sedimentation rate is about $5-6 \mathrm{~m} / \mathrm{m} . \mathrm{y}$.; it might have been higher during Pliocene and Quaternary. Such a foraminifera accumulation obviously implies both higher productivity and stronger winnowing of nannofossils than at Site 249. Possibly, currents over Mozambique and Madagascar ridges belonged to the same system.

Additionally, foraminifera assemblage studies lead to the supposition that during early Miocene time, the Site 246 area was at shallow depths and was affected by a transgression which thereby reworked older sediments (see Chapter 8). Afterwards, during the middle and late Miocene and Pliocene, the sea deepened and a rich planktonic fauna was deposited. Through the Pleistocene a considerable amount of benthonic fauna from lesser depths was added to the planktonic fauna, perhaps indicating uplifts in the vicinity. Since the early Miocene transgression, the site area seems to have undergone strong bottom current action.

\section{Cenozoic Clayey Nanno Ooze and Chalk of the Davie Ridge}

Figure 4 shows the importance of the insoluble fractions in the calcareous sediments of Site 242. The first question is to know whether this insoluble fraction is mostly pelagic or terrigenous in origin. X-ray analyses (Cook and Zemmels, this volume) yield sufficient data to determine the land-derived origin of most insoluble residues. In effect, reasoning on a carbonate-free basis, quartz and $\mathrm{K}$-feldspar contents appear to be very high, constituting about 20 to 30 percent of the minerals. Moreover, mica contents range from 20 to 40 percent and kaolinite is present also. The carbonate-free fraction of this facies appears quite similar to that at Site 241. Another significant point is the concentration of quartz and $\mathrm{K}$-feldspar in the $2-20 \mu$ fraction which means that this mineral suite constitutes a fine silty fraction. Therefore, this facies can no longer be attributed to true pelagic deposits but has to be referred to as a hemipelagite.

Sedimentation apparently was uninterrupted from late Eocene to Quaternary time at Site 242, which presents an opportunity to trace all the relative variations of pelagic and terrigenous contributions through this time span. First, the upper Eocene and lower Oligocene sequences are thin and, with a sedimentation rate of 5 to $7 \mathrm{~m} / \mathrm{m} . \mathrm{y}$., are very likely condensed. Heavy minerals and reworked foraminifera from lower and middle Eocene strata support this point. Displaced fauna are often abundant throughout a large portion of ths sediment column up to Core 16 but are much more disseminated above that level. Lithology studies show cyclic or oscillatory patterns which appear as increasing and decreasing insoluble residue contents. This may be explained by irregular winnowing and deposition related to fairly strong bottom currents. Upwards, the silt-sized fraction decreases, but the whole terrigenous fraction increases through late Oligocene and early Miocene times when the sedimentation rate reaches 15 to $18 \mathrm{~m} / \mathrm{m}$.y. This concomitant increase in both the rate of sedimentation and the terrigenous fraction suggests an increasing land-derived supply. It is striking to note that augmentation of terrestrial influx coincides with hiatuses in the Somali Basin.

The upper Miocene sequence exhibits a thick hemipelagic accumulation, implying an abnormally high rate of sedimentation, about 30 to $40 \mathrm{~m} / \mathrm{m} . \mathrm{y}$. This high rate coincides with not only an increase in nannofossil contributions by one-fifth (Figure 4), but also an augmentation of terrigenous mud supplies. It is very likely that this hemipelagic material was emplaced by mechanisms like bottom currents which are able to transport both nannofossils and terrigenous clays, forming nepheloid layers along the sea floor (Eittreim et al., 1969).

Thus, the lithology of the eastern flank of Davie Ridge involves the existence of low-energy currents over an area unaffected by tectonic activity, thereby allowing a continuous accumulation of sediment without any apparent hiatus.

The Oligocene clayey nanno chalk of Davie Ridge offers the unique possibility to link early Cenozoic nannofossils' depositional history of the Mascarene Basin to that of late Cenozoic nanno ooze in the Mozambique and Madagascar basins which have Oligocene hiatuses. This facies should present an opportunity to trace the evolution of nannofossils through Cenozoic times in the central western Indian Ocean. Although it is difficult to approximate the phytoplankton production from lithologic data because of dissolution and reworking, for instance, a general feeling emerges from the foregoing descriptions. It seems that a decrease in production occurred in the Oligocene and that microflora deposition was considerably reduced from the Eocene level. Similarly, the relatively increased Miocene production was again followed by a decline to the present. This fits very well with the conclusions of Tappan (1968) who attributes those fluctuations to contemporaneous physiographic modifications assuming that extensive epicontinental seas were at first favorable to phytoplankton growth.

\section{Biogenic Silica-Rich Facies}

The presence of high concentrations of radiolarians, diatoms, and even sponge spicules in a pelagic deposit are interesting because they are believed to indicate high nutrient level, i.e., to point to high productivity areas as discussed above. According to Lisitzin (1971b), more than 70 percent of the silica presently in suspension consists of diatoms, but in the equatorial belt radiolarians increase in importance. In addition, unlike calcium carbonate, 
apparently no critical depth (CCD) exists for amorphous silica because siliceous sediments are encountered at all depths.

Occurrences of Radiolaria and diatoms in the upper Miocene deposits of the Somali Basin are significant (Site 241). Increasing productivity, reaching a high level during the Pleistocene, is confirmed by the Site 240 lithologic record. Further, a few radiolarians and sponge spicules are seen in trace amounts in the Pleistocene deposits of the Davie Ridge. Consequently, one can assume that the present equatorial circulation pattern of the central western Indian Ocean was initiated by late Miocene times and was gradually enhanced during Pliocene.

The Neogene lithologic sequence of Site 239 apparently contradicts the foregoing, for radiolarians do occur in the Miocene, but subsequently they disappear in the Pliocene. These biogenic silica remains are included in a very particular facies which might have resulted from reworking and redeposition of sediments further north. Signs of reworking are indicated by the presence of displaced benthic foraminifera.

At other sites, especially in the Neocomian sequence of the Mozambique Ridge (Site 249), radiolarians seem to be closely associated with local volcanism.

\section{Brown Clay}

The mineral composition of brown clay has previously been discussed. Brown clay is the end member in a series of pelagic deposits which accumulate in a particular environment characterized by (1) a strong dissolution of calcium carbonate, and (2) a low rate of sedimentation of terrigenous and volcanogenic components, generally restricted to clay-sized material. This means that brown clay is deposited below the calcium compensation depth and away from highly productive areas. The CCD is, therefore, the depth of a facies boundary between calcareous ooze and brown clay which greatly depends upon sea-floor topography, deep bottom water circulation, and seawater chemical equilibrium. Thus, a brown clay facies is a good indicator in paleoenvironmental reconstructions.

Brown clay forms the end member of the Site 245 lithologic sequence which is a good example of a sedimentary column resting upon a spreading ridge below mid-latitudes and is similar to sedimentary columns in many other DSDP boreholes. At the bottom of Core 245-1, a late middle Miocene age was obtained from an intercalated clayey nanno ooze bed. Possibly, this layer was caused by the redeposition of nannofossils resuspended from neighboring upper slopes; a Paleocene assemblage was also observed in the same core. But, assuming that the time interval between initial deposition and redeposition for the youngest material is short, in other words negligible, the subsequent computed rate of sedimentation is about 1.5 $\mathrm{m} / \mathrm{m}$.y. This value is low but values of similar magnitude previously have been found, for example $2.5 \mathrm{~m} / \mathrm{m} . \mathrm{y}$. (Berger and von Rad, 1972). The lower boundary of the Site 245 brown clay facies was placed at 63 meters where intercalated nanno ooze gives an age of about $40 \mathrm{~m} . y$. , i.e., a total rate of sedimentation of $1.5 \mathrm{~m} / \mathrm{m} . \mathrm{y}$. This value does not warrant a break in the sedimentary column as a hiatus encompassing an Oligocene-early Miocene interval. Rather, the brown clay interval might be without any hiatus; more likely, it is condensed. The abnormally high amount of silt-sized material, which comprises about 23 to 30 percent, could favor such a hypothesis. Instead of denoting strong terrigenous influx, these high contents in silt-sized material could have resulted from the winnowing of the clay fraction. Removal of much of the clay-sized material would result in a concentration of the silt fraction and a lowering of the computed sedimentation rate.

The boundary between Site 245 brown clay and the underlying lithologic unit is well marked with the upward disappearance of intercalated thick nanno ooze beds. Thus, by middle late to late late Eocene, Site 245 was definitively below the CCD, which means either a subsidence of the area or, less simply, subsidence plus a rise of the CCD.

At Site 239, in the Mascarene Basin, brown clay and brown silty clay characterize the Paleogene series. Throughout the Paleocene, oozes were intercalated with the clay. The average sedimentation rate, if that hiatus exists, would range from 4 to $5 \mathrm{~m} / \mathrm{m} . y$. Terrigenous influx was important, especially during late Paleogene but beds of pure brown clay with very low silt-sized material content also occur.

The brown clay at the bottom of Site 248 is not quite similar. Presence of hematite and goethite attests to iron oxide influx, the source of which could be the underlying basalt. This facies is rather similar to iron-enriched basal sediments like those presently forming at the crest of the East Pacific Rise (Cronan et al., 1972).

\section{Minor Facies}

\section{Organic Carbon-Rich and Pyritic Facies}

At Site 241, concomitant occurrences of organic carbon and pyrite occur in noticeable amounts through middle Miocene to Pleistocene times. Evidently, one main factor responsible for such simultaneous occurrences is a high rate of sedimentation, about $35 \mathrm{~m} / \mathrm{m} . \mathrm{y}$. Frequently, in areas situated below high sedimentation rate zones, organic matter is rapidly buried, thereby favoring the development of sulfate-reducing bacteria which in turn initiates a reducing environment favoring organic matter preservation and pyrite formation. Another important factor must be the high organic matter productivity of water masses overlying the same area which provides organic carbon to the sediment. Presence of oxygen-depleted bottom water is not necessary to initiate reducing conditions as long as the rate of sedimentation and organic matter production remain at a high level. This authigenesis of pyrite connected with organic matter production supports the hypothesis of an increasing productivity of Somali Basin waters through late Cenozoic time.

The sedimentary column recorded from the east flank of the Davie Ridge is characterized by an apparently minor difference between lithologic Units II and III. The lower one (Unit III) displays brown hues whereas the overlying Units II and I are gray colored. These two gray units bear pyrite in trace amounts (burrow casts, streaks, etc.) and the gray hue is certainly closely related to the presence of iron sulfides. The color change occurs in the late early Miocene 
and very likely marks a considerable modification in redox conditions at that moment. Although the sedimentation rate is fairly high during late Cenozoic times, supplies of organic matter were certainly low as evidenced by low values of organic carbon contents $(0.1 \%-0.2 \%$ with the $0.2 \%$ significantly located in the Pliocene-Pleistocene sequences). Consequently, a more or less oxygen-depleted environment seems to be necessary and would have occurred by late early Miocene time and thence prevail until the late Pleistocene. According to Sverdrup et al. (1942), oxygen-depleted water flowing from the Red Sea and the Gulf of Aden presently passes over the Site 242 area. Oxygen minima are located at depths of about 1300 meters, but low oxygen contents extend down to about 2000-2200 meters (2.8-3.2 ml/L). Such oxygen-depleted waters allow initiation of reducing conditions at the sediment/water interface, especially when the sediment surface is heavily burrowed by bottom dwellers as was the case there. However, the top of Hole 242 is brown and apparently devoid of pyrite, which would mean that present conditions (during Holocene) do not initiate pyrite formation. It is very likely that the redox front moves through time according to climatic fluctuations, for instance, and presently is staying only for a short time just below the sediment/seawater interface. Presumably, an increasing flow of Antarctic Intermediate Waters would lower the depth of the oxygen-depleted, more saline water and so favor the occurrence of reducing conditions at the sediment surface (Sverdrup et al., 1942).

Thus, it seems reasonable to propose that a change in western water masses' circulation occurred by late early Miocene, which is marked by the color change in the sedimentary column of Site 242 described previously. This change would depend most probably on the arrival, at the entrance of the Mozambique Channel, of oxygen-depleted hypersaline deep water from the opening Red Sea and Gulf of Aden and also from the Arabian Sea. Presently those north Indian deep waters flowing south in the western Indian Ocean, between 1000 and 2000 meters depth, are known as the second principal source of low-oxygenated water which forms the extensive oxygen minimum in the upper circumpolar deep water (Callahan, 1972).

Other organic, carbon-rich pyritic facies like Cretaceous volcanic siltstone and claystone of the Mozambique Ridge (Site 249) seem related to local conditions characterized by high volcanic influxes associated with high benthonic productivity. The organic matter found in the Cretaceous flysch sequence of Site 241 might mainly originate from land-derived organic matter that was deposited in oxygen-deficient water.

\section{Black Ferromanganoan Facies}

This particular facies is described in detail elsewhere (Warner and Gieskes, this volume). Consequently, only environmental implications are discussed here and are restricted to Site 245. At Site 245 the carbonate-free fraction of the black ferromanganoan clayey nanno chalk is essentially montmorillonite with a brown to olive chalk matrix of amorphous matter containing mainly iron and manganese oxides. Very likely, the high amount of montmorillonite is related to volcanic ash devitrification processes similar to other montmorillonite accumulations. The importance of volcanic influences in the formation of this type of sediment is suspected by many authors (Bostrom and Peterson, 1969; Bostrom, Peterson, et al., 1969) who showed that low $\mathrm{Al} / \mathrm{Al}+\mathrm{Mn}+\mathrm{Fe}$ ratios are found in sediments resting on active ridges where a source should exist for volcanic emanations mixing with bottom waters as they debouch. The very close geographic proximity between active ridges and the low $\mathrm{Al} / \mathrm{Al}+\mathrm{Mn}+\mathrm{Fe}$ ratios in pelagic sediments has been well demonstrated. According to von der Borch et al. (1971b), the reasoning that ferromanganoan deposits are related to ridge crest volcanism is supported by the fact that iron-rich facies are present as a basal facies overlying basalt at all sites where it has been encountered. In effect, this basal sediment is quite similar to the surface deposit settling down over the crest of the East Pacific Rise. Thus, at Site 245, the basal iron-rich facies probably was formed when the basement was at the crest of the rise. The ensuing gradual removal of the site area from the ridge is well marked at Site 245 for the high montmorillonite content decreases through time. Strong volcanic influences are believed to last $12 \mathrm{~m} . \mathrm{y}$. at least which possibly means that volcanic ash might have been projected far away from the ridge crest. Several hypotheses were proposed to account for origin of iron-rich deposits such as submarine hydrothermal exhalations (Bostrom and Peterson, 1969) and leaching of nearly extruded basalt (Cronan et al., 1972).

The striking fact at Site 245 is that the ferromanganoan matrix, montmorillonitic phase, and nannofossils seem to be syngenetic. $\mathrm{Fe} / \mathrm{Mn}$ deposits do not appear as coatings but as amorphous agglomerates of very fine grains (Plate 3, Figures 5 and 6) formed and deposited nearly simultaneously with nannofossils. This indicates a very fast formation of $\mathrm{Fe} / \mathrm{Mn}$ oxides. Taxieff (1972) noticed that deep-water eruptions do not produce large pyroclasts such as bombs, lapilli, or pumice because hot lava ejecta is progressively fragmented during travel through water into silt-sized volcanic glass (hyaloclasts) and subsequently dispersed. This high fragmentation brings a large surface area of highly reactive material in contact with water which greatly favors chemical reactions. One of them would be halmyrolysis of palagonitic material with release of insoluble Fe-Mn oxide, calcium, and silica. Such reactions should be very fast and might produce a sort of rain of insoluble $\mathrm{Fe}-\mathrm{Mn}$ particles which slowly settle while accreting more $\mathrm{Fe}-\mathrm{Mn}$ ions and mixing with nannofossils. Simultaneously, a calcium-enriched environment would favor the precipitation of calcite as rhombs or as overgrowths.

Evidently, apart from any speculations, ferromanganoan deposits characterize, to some extent, the most active ridges and according to Bostrom et al. (1969), those with high heat flow and associated high spreading rate. The ferromanganoan content in the basal sediments at Site 245 implies a similar origin.

\section{Silicified Chalk and Chert-Lithification of Chalk}

Chert and silicified chalk were found only in the Madagascar Basin, at Site 245 in subunit IIIB (see Chapter 7). Problems of chert formation and origin have been 
previously well studied mainly by Rex (1970), Rex and Murray (1970), Calvert (1971), Mattson and Pessagno (1971), von der Borch et al. (1971a), Berger and von Rad (1972), Wise et al. (1972), and Weaver and Wise (1972). The purpose of this section is not to review these works but to emphasize one special point characterizing Leg 25 chert. The late Paleocene and early Eocene chert-bearing lithologic unit is practically devoid of any siliceous tests but is rich in montmorillonite. This point could support the contention of Gibson and Towe (1971) that volcanic derivatives, rather than purely biogenous production, may be an important source of silica for chert.

Fresh broken surfaces of chert and mainly of a silicifed chalk directly in contact with a brown chert bed are depicted from scanning electron microscope pictures, shown in Plates 1 and 2. Spherulites consisting of thin blade-like crystals, radiating in disorder out of the spheres, are seen filling foraminifera test cavities. These spherulites and agglomerates of spheres are identical to those described by Wise and Hsu (1971) and identified as cristobalite. Further, X-ray analysis of a silicified chalk (Core 9, $312 \mathrm{~m}$ ) denotes the presence of predominant cristobalite with montmorillonite and tridgmite. In Plate 1, Figures 1 and 2, molds of recrystallized calcite crystals of a foraminifera test, removed by the fraction section, are clearly visible, as well as the cristobalite blades. It appears that in some places spheres are connected both to each other and to the foraminiferal chamber wall by a network of thin filaments (Plate 1, Figures 5 and 6; Plate 2, Figure 1). One figure seems to be typical of the boundary between silicified chalk (with spherulites) and massive chert, where all features disappear except for ghosts of foraminifera (Plate 2, Figure 5). Spherulites are often replaced by sheaves of cristobalite blades more or less interlaced (Plate 2, Figures 2, 3,4) and are seen either as fillings of foraminifera tests or in pores of the chalk.

What appears in a conspicuous manner is the well-marked difference between silicified chalk and the true chert stringer. Within the former, nannofossils, authigenic calcite rhombs, overgrown test fragments, and cristobalite spherulites are clearly visible. Within the latter, all those features disappear and are replaced by mainly homogeneous material where ghosts of fossils can be seen. Obviously, there are two different steps in the silicification. Possibly, the occurrence of a filament network indicates the beginning of the filling of foraminiferal chambers, the first step in "chertification."

The origin of silica remains speculative. An absence of siliceous fossils-unless they have all been dissolved which is difficult to believe-implies another source. High content in montmorillonite of the chalk and abundance of devitrified volcanic ash in the underlying lithologic unit suggest that a predominant part of silica comes from the devitrification of volcanic glass. According to Gibson and Towe (1971), the opal-cristobalite-montmorillonite suite is indicative of altered volcanic glass. Silica could pass into solution in interstitial waters and migrate over distances of centimeters or meters (Weaver and Wise, 1972) and even more until a high-porosity layer, a foram-rich layer for instance, is reached. There, mobilized silica might reprecipitate as cristobalite blades with prisms of foraminifera tests acting as a catalyst and support.
So, independently of chert, silica and especially volcanically derived silica might play an important part in the lithification of nanno ooze. As assessed by Wise and Hsu (1971), lithification of deep-sea chalk could have been accomplished by chemical precipitation of two types of cement: (1) cristobalite as spherules or sheaves filling large pores; and (2) calcite occurring as secondary overgrowths and euhedral crystals. From scanning electron microscope examinations, it clearly appears that what is designated as "micarb" is composed of overgrown nannofossil plates, but not always in major amounts. Micarb could also be calcite prisms of desegregated foraminifera tests (near the lysocline?) more or less recrystallized or overgrown.

\section{DEPOSITIONAL PALEOENVIRONMENT- CHANGES THROUGH THE CENOZOIC}

\section{Late Cenozoic Changes in Productivity at the Onset of the Equatorial Water Mass Circulation}

As discussed previously, increasing content in siliceous fossil, foraminifera, and organic carbon contents in bottom deposits indicates increasing biogenic production of the overlying water masses. Presently, the equatorial zone is known to be one of the regions of high organic production which is related to upwelling induced by divergences.

According to Olausson (1971), in the three major oceans, the south equatorial divergence apparently is the most important because the rate of production is high. Today, it lies at about $8^{\circ}$ to $12^{\circ} \mathrm{S}$ in the central western Indian Ocean. Despite the fact that it is still not very well documented, one can expect that upwellings are not steadily developed and hence not quite comparable to those in the Atlantic and Pacific oceans. In effect, the equatorial Indian Ocean circulation pattern is strongly altered by a semiannually reversing monsoon regime in relation to the vicinity of continental masses, particularly Southeast Asia and the Indian subcontinent. Consequently, whereas the east-west-flowing south equatorial current is permanent because the Southeast Trade Winds are permanent, the north equatorial gyre is strongly modified in winter by the southwest monsoonal wind which induces the Somali Current. If the location of India is presently very important regarding the development of the monsoonal regime in the central western Indian Ocean, its paleoposition is evidently a major point too. As long as India was at south latitudes or below the equator, the presence of an equatorial circulation system was not allowed to develop. According to the McKenzie and Sclater (1971) reconstruction, the south part of India and Ceylon were still south of the equator by Oligocene times (Figure 5). It is most likely that an acceleration of spreading in the north central Indian Ocean by early to mid-Miocene times led to a northward drift of India. This movement might be correlated to the uplift of the Himalayas (Laughton, McKenzie, and Sclater, 1972). The first signs of equatorial biogenic production are seen in upper Miocene deposits of the Somali Basin. Consequently, it can be inferred that the onset of the equatorial circulation pattern was initiated as soon as India was sufficiently beyond the equator. India is believed to have crossed the equator in the Miocene (McElhinny, 1970). 


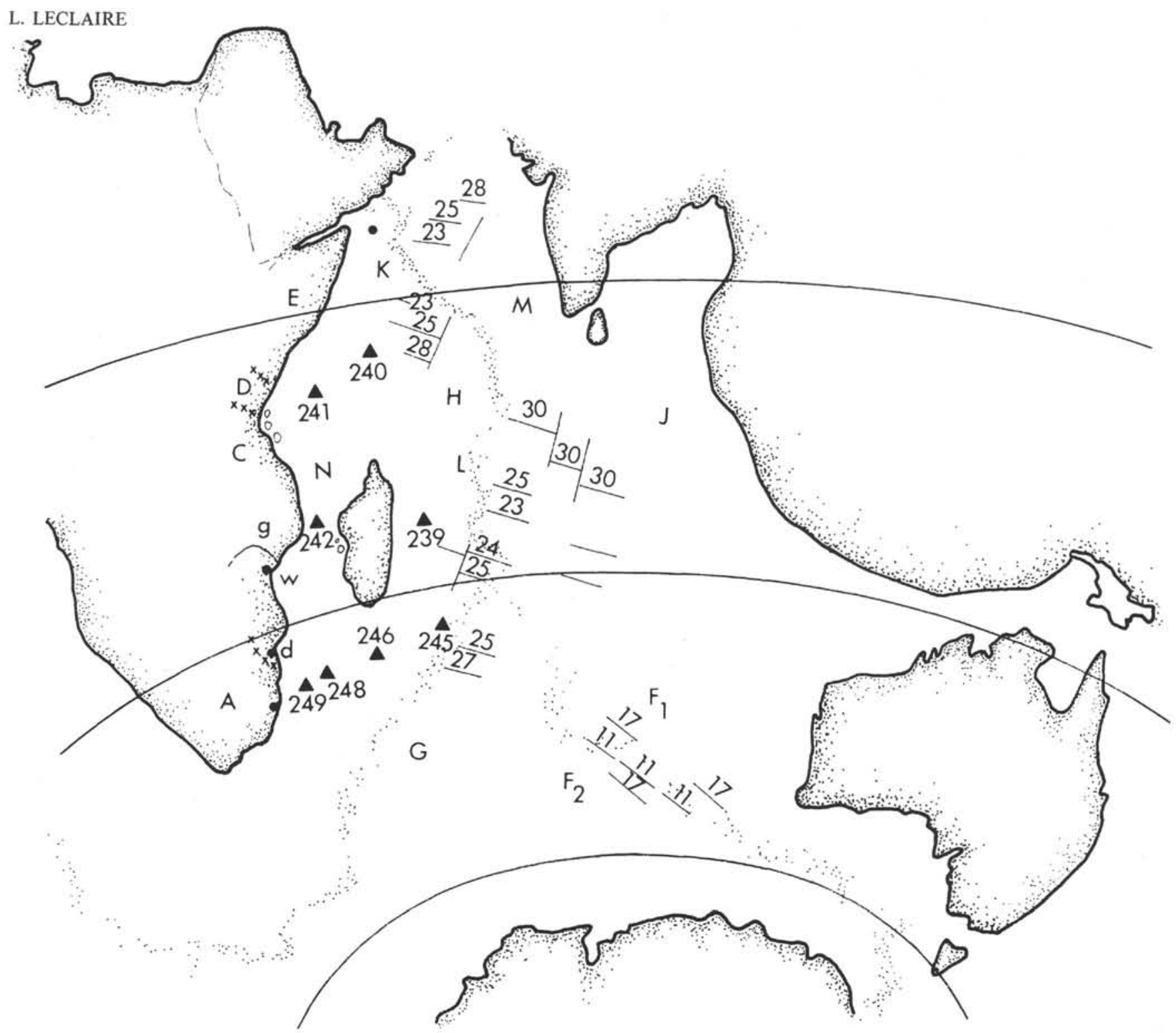

\section{LEGEND}

A SOUTH AFRICA
B MOZAMBIQUE
C TANZUNIA
D KENYA
E HORN OF AFRICA
F $_{1}$ BROKEN RIDGE
$\mathrm{F}_{2}$ KERGUELEN

G CROZET

H SEYCHELLES

J NINETYEAST RIDGE

K CARLSBERG RIDGE

L MASCARENE RIDGE

M MALDIVE-LACADIVE ISLANDS

N COMORO ISLANDS

- HELOSIE
- VAUCLUSE
$\times$ EPONGE
a MAJUNGA BASIN
b MORANDAVA BASIN
d LOURENCO MARQUES
g ZAMBEZI RIVER
i DURBAN

Figure 5. Early Oligocene reconstruction of the Indian Ocean (36 m.y.) (according to McKenzie and Sclater, 1971).

Simultaneously, Gulf of Aden was created and the Arabian Sea widened as Carlsberg Ridge was spreading, and depending upon climatic conditions, warm and saline waters probably were formed in these seas with a low oxygen content. Initiation of their circulation (to the south) would have taken place by early middle Miocene and might be the cause of the redox change over the Davie Ridge area. It has been noted previously that these oxygen-depleted waters are known presently as the north Indian deep waters which still flow southward. This circulation through the Mozambique Channel seems to be blocked today at $20^{\circ} \mathrm{S}$. Tchernia et al. (1951) pointed out that the influence of Arabian waters is limited to $20^{\circ} \mathrm{S}$ in the Mozambique Channel because of the hydrological and thermal barrier which obstructs the propagation of the Antarctic Intermediate Waters toward the north and the 
Arabian Sea waters toward the south. This barrier, due to strong contrast between the two water masses, causes a stagnation of the deep waters over Davie Ridge and if this existed in the past, might have contributed to oxygen impoverishment of bottom water near Site 242 .

Thus, a change in the circulation system of the central western Indian Ocean waters very likely took place by early middle Miocene and gave rise to the present circulation pattern. Is it possible to find any signs of the previous circulation system? It is tempting to assume that the Mozambique vortical circulation (Harris, 1972) was not initiated by Pliocene times or even by late Oligocene, but earlier. In effect, a big hiatus encompasses about 40 m.y. (early and middle Cenozoic) at Site 249. This is by far the greatest hiatus, which suggests either a stronger action of bottom currents, or more likely, a longer duration. Frakes and Kemp (1972) postulated the existence of a western prolongation of the South Equatorial Current of the Pacific Ocean into the Indian Ocean during Eocene and Oligocene times through a north Australian seaway (Figure 6). This current, deflected southward by India to the east Madagascar and the southeast African coast, would have had the same effect as the present Indian Ocean South Equatorial Current which is a vortical circulation pattern over Mozambique Ridge and Mozambique Basin (Agulhas Current).

The great oceanic gyre postulated by Frakes and Kemp (1972) would have passed north of the Site 245 area, contouring waters similar to the present CentralWater Masses.

\section{Mid-Cenozoic Hiatuses and Deep Bottom Water Circulation}

\section{Introduction}

Important breaks in the sedimentary columns were detected in Leg 25 cores. Most are true hiatuses, as at Sites 241 and 249, but some may be restriced to condensed sequences as discussed before for Site 245. Comments about hiatuses are made elsewhere (Sigal, this volume; Kent, this volume). Figure 2 indicates that hiatuses involve mainly pelagic deposits or, at least, are marked by clear changes in sedimentation. This is the reason the important problem of hiatuses is shortly discussed in this chapter. Reinterpreted hiatuses and condensed series are depicted together with some major events of the Cenozoic Indian Ocean history (Figure 7).

First of all, one must bear in mind that hiatuses are "asymmetrical." According to Pimm and Hayes (1972), the change from sedimentation to nondeposition or erosion may represent the reaching of an erosional level which does not necessarily correspond to the beginning of an associated physical event. On the contrary, it is the end of the hiatus which dates the end of the physical event action. Following this reasoning, most attention has been given to the termination of Leg 25 hiatuses (Figure 7).

It is striking to note that mid-Cenozoic hiatuses end by late Oligocene-early Miocene time in eight different sedimentary columns raised from the central western Indian Ocean. The earliest end is late Oligocene in age at Sites 241

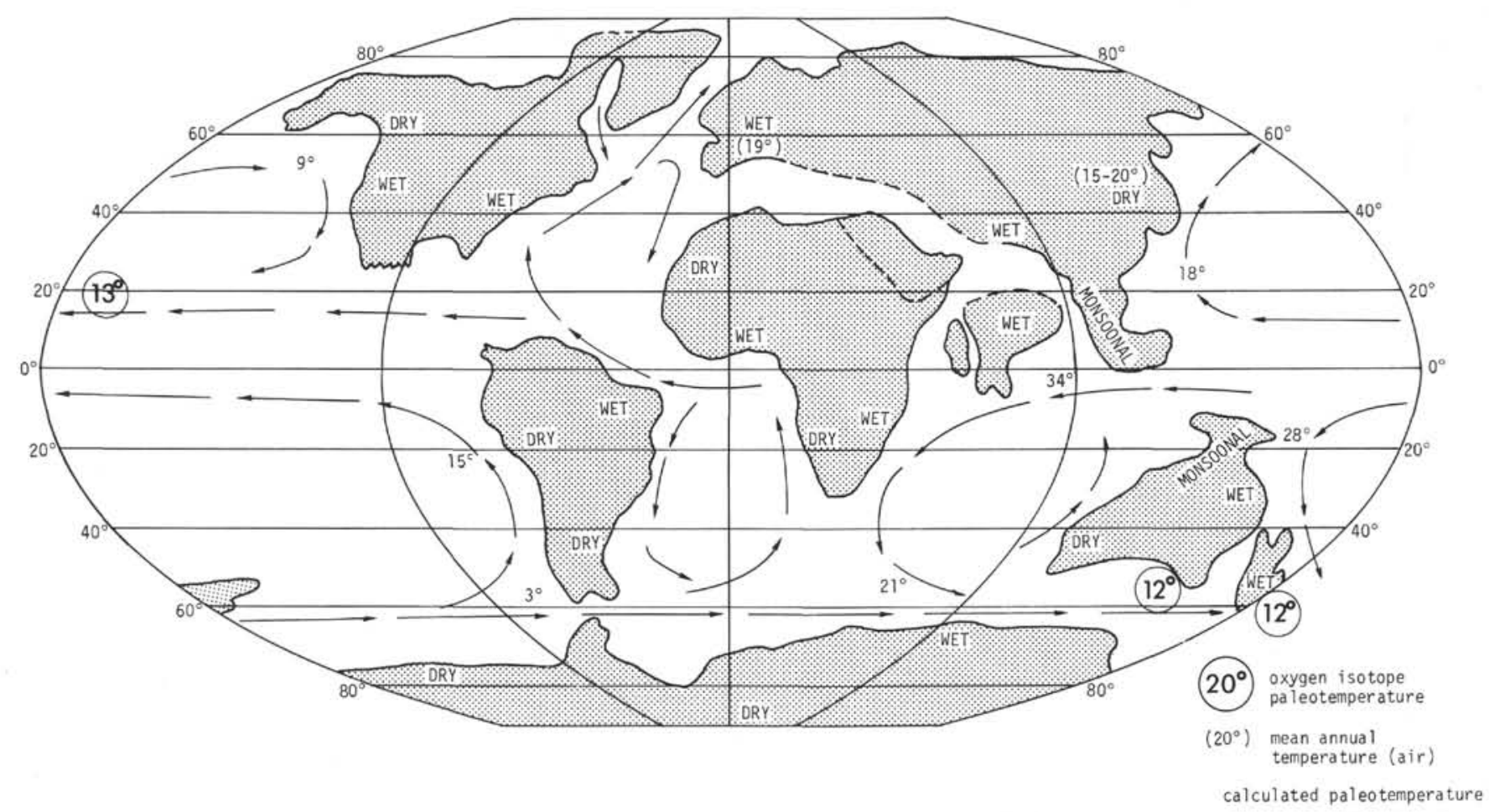

Figure 6. Mid-Oligocene global circulation patterns. Note the counter-clockwise gyral in the Indian Ocean, in the prolongment of the South Equatorial Current coming from the Pacific Ocean. Madagascar Island is mislocated (according to Frakes and Kemp, 1972). 
L. LECLAIRE

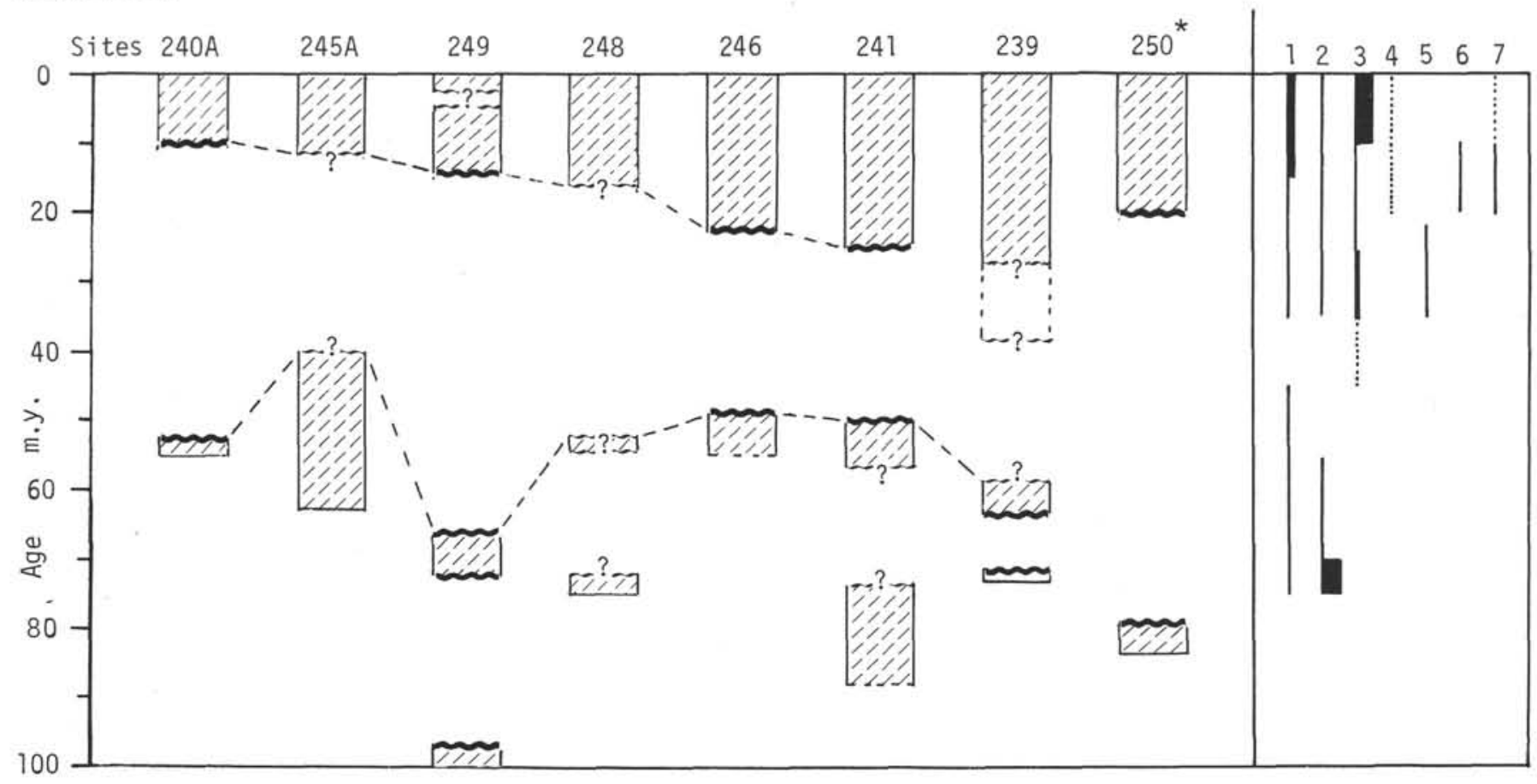

1. Epochs of notable spreading in the Central Indian Ocean.

2. Spreading of Indian Ocean.

3. Spreading between Antartica and Australia.

4. Down warping of Madagascar Plateau.

5. 01igocene regression on East African coast.

6. Miocene transgression on East African coast.

7. Uplift of the Southwestern Branch.

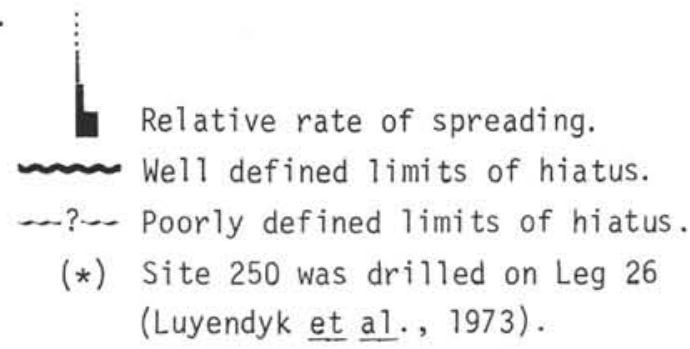

Figure 7. Central western Indian Ocean hiatuses and major events of the Indian Ocean history. (1) epoch of notable spreading in the central Indian Ocean; (2) spreading of India and period of high spreading rate; (3) spreading between Antarctica and Australia, note the acceleration; (4) uplift of the southeast branch (?); (5) downwarping of the Madagascar Plateau; (6) oligocene regression on East African coast; (7) miocene transgression on East African coast.

and 239, and the latest is early Miocene in age at Site 249. At Site 239 , the end is not sharp and seems to be preceded by a condensed series, whereas at Site 245 the cause of the hiatus (or condensed sequence) might have not completely ceased from middle Miocene to Pleistocene.

Those mid-Cenozoic hiatuses appear roughly-but not strictly-synchronous throughout areas as different as Somali Basin, Mascarene Basin, and Mozambique Ridge. Such hiatuses are not specific to the central western Indian Ocean but are worldwide (Pimm and Hayes, 1972). Consequently, it can be concluded that the primary causes are worldwide phenomena.

\section{Hiatuses and Deep Bottom Currents}

Many authors are generally in good agreement when ascribing hiatuses to deep bottom current effects. Fox et al. (1968) have shown that the strongest bottom currents in the North Atlantic are along the continental rise and adjacent abyssal plain off the east coast of North America (western boundary undercurrent). Sites 99, 101, and 105, which were drilled in the same area (Ewing, Hollister, et al., 1970), showed hiatuses of extremely long durations. (70-110 m.y.). This is not coincidental, and suggests that similar western boundary undercurrents have been in existence throughout the Cenozoic.
Johnson and Johnson (1970), studying sediment distribution by bottom currents in the central Pacific, ascribed the presence of old sediments at or near the floor, to the existence of currents of sufficient magnitude to prevent sediment accumulation. Antarctic Bottom Water has been observed entering the Pacific Ocean south of New Zealand and flowing northward as an intensified western boundary current (Johnson, 1972a, 1972b). Strong effects of bottom-water activity have been evidenced around Antarctica (Hollister and Elder, 1969; Watkins and Kenneth, 1971; Kenneth and Brunner, 1972; Fillon, 1972; and others). Kenneth (1972) ascribed hiatuses in the Southwest Pacific to paleocirculation changes related to the Australia-Antarctica separation and the onset of glaciations.

Thus, the relation between hiatuses and deep bottom currents, especially western boundary undercurrents, is fairly well documented, and it is not unreasonable to think, as a working hypothesis, that similar currents were operating in the central western Indian Ocean by mid-Cenozoic times.

\section{Deep Bottom Currents in the Indian Ocean}

Current scours, ripples, and lineations were observed by Heezen and Hollister (1964) south of Reunion Island, south 
of Rodriguez Island, and on the Madagascar Ridge. Other evidences of current action are found on the eastern and western flank of the mid-Indian Ridge. Ewing et al. (1969) noticed that the southwest branch of the mid-Indian Ridge has a well-defined, wide band barren of sediment over the crest and emphasized the concept of current control of sedimentation.

Although very little is known of present bottom-water circulation, Antarctic Bottom Water is believed to penetrate deep areas in the southwestern part of the Indian Ocean according to bottom-water potential temperature studies. Le Pichon (1960) thought that: "a deep current toward the north, having the characteristic of a western boundary current is deflected and weakened by the complex ridge system." Flows of Atlantic Deep Water, strengthened by a similar flow of Antarctic Bottom Water, apparently would enter the Mozambique Basin. It is striking that in the same area Ewing et al. (1968), have shown sedimentary features termed "giant ripples" evidencing the strong influences of bottom currents. Le Pichon (1960) further postulated another similar western boundary current flowing northward and adjacent to Madagascar through the Macarene Basin. The existence of this current has been recently confirmed by Warren (1971). This current is wide and by $23^{\circ} \mathrm{S}$, it exists as a northward flow immediately adjacent to Madagascar and a less pronounced one in the central part of the basin near longitudes $57^{\circ}-62^{\circ} \mathrm{E}$. This is a confirmation of Le Pichon's suggestion. Other investigations (Leclaire and Duplessy, Osiris cruise onboard Marion Dufresne, 1973, unpublished results) support the existence of this current. An erosional surface was seen at the top of a pilot core raised from the South Mascarene Basin. Hydrological measurements suggest a passage of Antarctic Bottom Water through the Southwest Indian Ridge, south of Rodriguez Island (A. Tanguy, personal communication).

Harris (1972) has found that mixing of great water masses coming partly from the equatorial circulation system, and more explicitly from the South Equatorial Current, gives rise to a vortex pattern with giant vortices over Mozambique and Madagascar ridges, probably down to 1000 to 2000 meters depth. No doubt, Recent and Pliocene-Pleistocene winnowings seen at Sites 249 and 246 are closely related to this circulation as is the Pliocene-Quaternary condensed series (or hiatus) at Site 249 . Other probably effects of this circulation pattern were seen by Saito and Fray (1966) who reported the presence of mixed assemblages including Upper Cretaceous, Eocene, Miocene, and Recent foraminifera found in two cores from the flank of Mozambique Ridge and assumed erosion by currents of outcropping at high elevations on the ridge. It is worthwhile to note in passing that Eocene sediments seem to be present at places on the Mozambique Ridge whereas they are absent at Site 249 , which strongly suggests bottom erosion.

Summarizing, two main circulation patterns presently exist in the central western Indian Ocean: (1) a deep bottom circulation pattern related to Antarctic Bottom Water flowing northwards, and (2) a surface to subsurface current pattern more or less derived from the equatorial system.

The fact that mid-Cenozoic hiatuses are found in regions where those currents have been described cannot be coincidental. Hiatuses at Sites 240 and 241 are apparent exceptions, but no data are available concerning a deep bottom current in the Somali Basin. However, a prolongment of the western boundary current from Mascarene Basin into Somali Basin is probable. Thus, the hypothesis that the same deep bottom circulation was acting in the past must be discussed.

The present source of Antarctic Bottom Water is mainly the Weddell Sea (Jacob et al., 1970) and is closely related to Antarctic ice-sheet influence which cools the shelf waters. According to Frakes and Kemp (1972), the warm and wet conditions which apparently characterized latitudes beyond $45^{\circ}$ in the late Eocene were altered during the Oligocene to conditions more like the present, with cool surface waters. Glomar Challenger boreholes from Wilkes Land Abyssal Plain (Hayes, Frakes, et al., 1973) indicate cool temperatures over this area in the late Oligocene-early Miocene. Consequently, formation of cold water in the Weddell Sea by Oligocene times is quite probable even if the Antarctic ice sheet was not fully developed. Following this reasoning, Antarctic Bottom Water, flowing northward, may have existed by Oligocene time and may have supplied a western boundary undercurrent in the western Indian Ocean. If hiatuses are ascribed to those currents, a considerable weakening of their vigor from mid-late Miocene until present time must have occurred. This assumption is apparently in opposition with the fact that South Atlantic hiatuses (Berger, 1972) show a considerable increase of the Antarctic Bottom Water flow related to the growth of the Antarctic ice sheet and the onset of glaciation. In fact, the solution is contained in a remark of Le Pichon (1960) cited before, i.e., that the western boundary current has been deflected and weakened by a complex ridge in middle Miocene time as well as presently. This complex ridge system was the same as today, the southwest branch of the mid-Indian Oceanic Ridge which thereby suggests a strong uplift of the ridge beginning in the late Oligocene-early Miocene. This point is strongly supported by Sclater and Harrison (1971) who postulated the formation (or reactivation) of the southwest branch 20 million years ago and can be correlated to the general Miocene transgression over the East African coast (Kent, this volume; Sigal, this volume).

Consequently, deep western Indian Basin hiatuses are believed to be related to western boundary current action initiated by late Oligocene-early Miocene time. These currents stopped and hiatuses ended gradually when uplift of the south west branch took place. This complex ridge system acted and is still acting as a barrier, partly blocking and considerably weakening western boundary currents.

Presence of hiatuses at Sites 249 and 246 cannot be similarly explained and the fact that they ended at about the same time as the others seems like a coincidence. Obviously, those hiatuses may have been originated from the vortical circulation of the Agulhas-Mozambique system described before. But this circulation is connected with the equatorial system which supposedly started by middle-late Miocene, i.e., when hiatuses ended. Apparently, there is a dilemma here. Moreover, during Eocene and Oligocene times, an east-west water mass drift may have replaced the present South Equatorial Current. Additionally, Frakes and Kemp (1972), who determined global paleoclimates from a 


\section{LECLAIRE}

reconstruction of past positions of continents, drew a great counter-clockwise gyral (Figure 6) originating from the South Equatorial Pacific Water entering the Indian Ocean through a north Australian seaway (as mentioned before) during Eocene and Oligocene. Both flows may have acted similar to the present South Equatorial Current and were perhaps even stronger, which possibly gave rise to a similar vortical circulation pattern over Mozambique and Madagascar ridges where strong reworking of older material was seen in the upper Cenozoic pelagic deposits. The end of liatuses seems to correspond to changes in the circulation pattern and to the onset of the equatorial current system.

Older hiatuses encompassing Late Cretaceous (Sites 241 and 239) or middle Late Cretaceous (Site 249) are without apparent correlation. They are too poorly documented to attempt speculations or interpretations. However, it seems very likely that they were caused by comparable events but probably were more restricted.

\section{Changes in CCD and Weathering of Fresh Basaltic Basement}

The CCD is the facies boundary between brown clay and calcareous ooze according to Berger and von $\operatorname{Rad}(1972)$. It marks the level where the rate of dissolution is compensated by the rate of supply. Foraminifera are dissolved first and many of them, more soluble, go into solution considerably above the CCD. Fragmented tests and concentration of resistant species are the first signs of dissolution and mark the level of what Berger (1968) named the foraminifera lysocline.

Because CCD is related in part to depth of the sea floor, an attempt to trace paleodepths of some Leg 25 sites is made here. Depth as a function of age of five sites has been plotted on the Sclater and Harrison age-depth constancy diagram (Figure 8). Site 249 appears to be anomalous as expected. Sites 239 and 245 plots are distributed slightly above the average theoretical curve. Sites 248 and 240 plots fit fairly well. Given the fact that ages are based on fossils

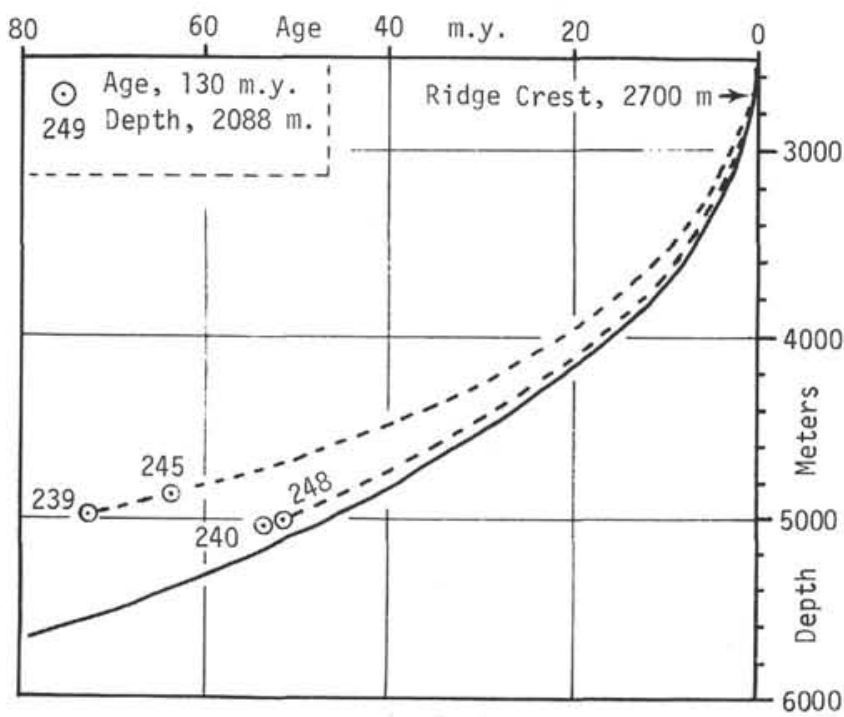

Figure 8. Depth as a function of age (from Sclater and Harrison, 1971). Note the position of some Leg 25 sites. overlying basalt, scatter is not surprising; it was noticed previously (Berger and von Rad, 1972) and ascribed to possible relative uplift.

Using Berger's back-tracking method, paleodepths of Sites 239 and 245 through time were obtained (Figure 9). The CCD was inferred from lithologic and micropaleontologic data. It appears that at Site 239 the CCD reached the sea floor at about 3600 meters depth, 10 m.y. after the
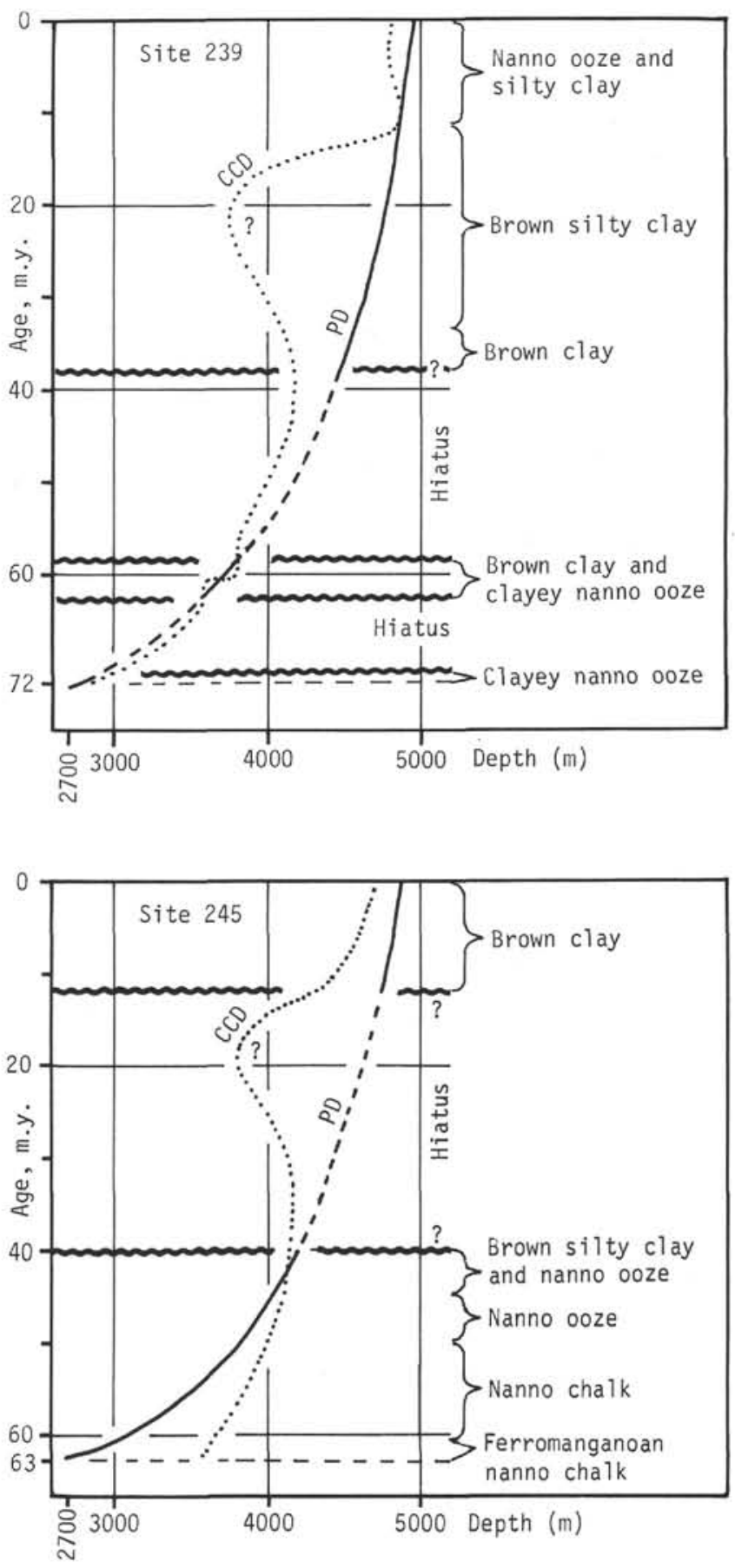

Figure 9. Paleodepths and CCD through time of Sites 239 and 245, according to Berger's (1972) back-tracking method. 
site was created, that is, by early Paleocene but was very close before. At Site 245, the CCD reached the sea floor at 4100 meters depth 20 m.y. after the site was created, at late Eocene, and has stayed above until the present time.

Hiatuses or condensed sequences severely curtail many data on CCD fluctuations through the Cenozoic. However, it can be assumed that the CCD was higher in early Cenozoic than later. This is supported by the Site 248 record where dissolution signs are shown a very short time after basaltic "basement" was emplaced. Afterwards, Site 245 seems to indicate a deepening of the CCD, reaching depths of 4100 meters by the middle Eocene. The CCD and the foram lysocline were certainly quite deep by late Eocene and Oligocene as evidenced from the Site 242 lithologic column which exhibits a fairly good preservation of foraminifera assemblages through this period.

Another important change in the CCD and the foram lysocline depth marks the late Cenozoic, especially middle Miocene. This phenomenon is well documented at Sites 242 and 241 where strong signs of dissolution were observed. This high elevation of the foram lysocline is a large-scale phenomenon for it is well established in the Atlantic Ocean (Berger, 1972; Berger and von Rad, 1972). This elevation was followed by a rapid drop at the end of the Miocene by as much as 1000 meters in the Atlantic Ocean. Nothing contradicts a similar evolution in the western Indian Ocean. On the contrary, increasing calcareous rates of sedimentation at Sites 241 and 242 by the end of the Miocene favor this interpretation. Furthermore, Site 250, occupied during Leg 26 (Luyendyck, Davies, et al., 1973), displays evidences for an important drop of the foram lysocline from an initial depth of about 2500 meters by late Miocene time.

What might have caused those CCD fluctuations? Presently, the foram lysocline is shown to roughly correspond to the top of the Antarctic Bottom Water in the Atlantic Ocean (Berger, 1968; Edmond, et al., 1971). There is evidence that the lysocline was several hundred meters shallower during glacial stages than now in the Atlantic Ocean which suggests that during glacial time the Antarctic Bottom Water was formed more rapidly and in greater quantities. But this analogy, relevant to Pleistocene, cannot account for the great Cenozoic variations of the foram lysocline and the CCD.

A comparison of ages of great events marking the Indian Ocean history and of the CCD changes shows possible correlations. The deepening of the CCD through early middle Cenozoic time followed a period of high rate of spreading floor characterized mainly by the northward drift of India (Laughton et al., 1972). But during middle Cenozoic, the spreading either stopped or was very slow; this event was followed by a rise of the CCD during early Miocene. In the early Miocene the direction of relative motion changed and spreading started again with uplift of the southwest branch. This event was followed by a sharp drop of the CCD in late Miocene. These changes in spreading rate are large-scale events as shown by Fleming and Roberts (1973). In checking correlation between eustatic changes and spreading discontinuities, they found that there was a global deceleration in spreading at about 45 m.y. and a global acceleration at 10 m.y. Berger (1972) stated that in the Atlantic Ocean the CCD raised considerably by early Miocene and then dropped sharply in the late Miocene.

Consequently, changes in the CCD seem to be worldwide and associated with worldwide discontinuities in spreading rates. Apparently, there is no direct link between the two pheñomena. However, an exciting suggestion by Hart (1973) might account for CCD variations in the past if his idea is confirmed by further investigations. Hart has established a detailed synthesis of the evidences for large-scale chemical reactions between seawater and the ocean floor basalt. A striking point is that the chemistry of basalt emplaced at ridge crests varies progressively with distance from the sea-floor spreading ridge, probably because of leaching of elements and halmyrolysis of the basalt layers. These reactions release to seawater not only $\mathrm{Fe}$ and $\mathrm{Mn}$ (which is expected) but also calcium in great amount. Supplies of calcium in seawater can greatly modify equilibrium between calcareous sediments and seawater and so change the CCD level. Maximum releases of calcium to seawater obviously accompany and follow creation of new crust, i.e., reactivation or acceleration of sea-floor spreading, while minimum releases follow either deceleration or stops of spreading which maintains the basalt contact with seawater (unless basalt is buried under sediments).

The relation previously discussed between the Antarctic Bottom Water and foram lysocline is probably due to the fact that this water is the most "aggressive" because of its long travel below high organic productive zones and of the ensuing enrichment in $\mathrm{CO}_{2}$. The onset of the strong pole to pole and circumpolar Antarctic circulation in relation to the Antarctic ice-sheet growth might explain the sharp CCD drop by late Miocene time. This new global circulation must have considerably accelerated the mixing of waters and subsequently the diffusion of calcium.

\section{CONCLUSIONS}

Obviously, the preceding interpretations are highly speculative, but they are based on facts which, despite the dispersion of sites and the diversity of occupied areas, are significant. Presumably, the main conclusion is that pelagic sedimentation fluctuated through Cenozoic times according to some dominant factors which might include the following: (1) onset of the equatorial circulation system at late Miocene and subsequently the increase in biogenous productivity mainly are the Somali Basin; (2) onset of western boundary undercurrents by late Oligocene time and the ensuing lack of sedimentation and considerable bottom erosion in the Somali, Mascarene, and Madagascar basins; (3) blockage of most of the northerly water flow when the southwest branch of the mid-Indian Ridge was uplifted and began acting as a barrier; (4) persistence of a strong vortical circulation pattern over the Mozambique Ridge area at least through middle and late Oligocene and early Miocene; (5) variations of the CCD and the ensuing modification in space and time in the distribution of calcareous ooze and brown clay.

Finally, onset of the equatorial circulation was dependent upon widening of the north central Indian Ocean and the northward drift of India while deep bottom 
circulation was orographically controlled. CCD variations seem to be related to the rates of production and weathering of fresh basaltic basement. Thus, paleoenvironment and hence pelagic sedimentation through Cenozoic times was primarily controlled by sea-floor spreading.

\section{ACKNOWLEDGMENTS}

Carbon carbonate analyses are from the DSDP laboratory supervised by $\mathrm{J}$. Bodie. The X-ray analyses were carried out by I. Zemmels and H. E. Cook at the University of California, Riverside, California.

The author especially wishes to thank T. L. Vallier who edited and checked the manuscript for style and logic and who advised and encouraged the author during the preparation of this manuscript.

\section{REFERENCES}

Arrhenius, G., 1963. Pelagic sediments. In Hill, M. N. (Ed.), The Sea; New York (Interscience) v. 3, p. 655-727.

Bé, A. W. H. and Tolderlund, D. S., 1971. Distribution and ecology of living planktonic foraminifera in surface waters of the Atlantic and Indian oceans. In Funnel, B. M. and Riedel, W. R. (Eds.), The micropaleontology of oceans: Cambridge (Cambridge University Press), p. 105-149.

Berger, H.W., 1968. Planktonic foraminifera: selective solution and paleoclimatic interpretation: Deep-Sea Res., v. 15, 31-43.

1972. Deep sea carbonate: dissolution facies and age-depth constancy. Nature, v. 236, p. 392-394.

Berger, H.W. and von Rad, U., 1972. Cretaceous and Cenozoic sediments from the Atlantic Ocean: In Hayes, D. E., Pimm, A. C., et al., Initial Reports of the Deep Sea Drilling Project, Volume 14: Washington (U.S. Government Printing Office), p. 787-955.

Bezrukov, P.L., 1971. Zonation of biogenous sedimentation in the ocean. In Funnell, B. M. and Riedel, W. R. (Eds.), The micropaleontology of oceans: Cambridge (Cambridge University Press), p. 219-221.

Biscaye, P.E., 1965. Mineralogy and sedimentation of recent deep sea clay in the Atlantic Ocean and adjacent seas and oceans: Geol. Soc. Am. Bull., v. 76, p. 803-832.

Bostrom, K. and Peterson, M. N. A., 1969. The origin of aluminum-poor ferromanganoan sediments in areas of high heat flow on the East Pacific Rise: Mar. Geol., v. 7, p. $427-447$.

Bostrom, K., Peterson, M. N. A., Joensuu, O., and Fisher, D. E., 1969. Aluminum-poor ferromanganoan sediments on active oceanic ridges: J. Geophys. Res., v. 74, p. 3261-3270.

Bramlette, M. N., 1958. Significance of coccolithophorids in calcium-carbonate deposition: Geol. Soc. Am. Bull., v. 60, p. 121-126.

Callahan, J. E., 1972. The Structure and circulation of deep water in the Antarctic: Deep-Sea Res., v. 19, p. 563-575.

Calvert, S.E., 1971. Nature of silica phases in deep sea cherts of the North Atlantic: Nature Phys. Sci., v. 234, p. 133-134.

Cayeux, L., 1935. Les Roches Sedimentaires de France. Roches Carbonatées, v. 1: Paris (Masson and Cie).

Cronan, D. S. et al., 1972. Iron-rich basal sediments from the eastern equatorial Pacific: Leg 16, Deep Sea Drilling Project: Science, v. 175, p. 61-63.

Edmond, J. M., Chung, Y., and Sclater, J. G., 1971. Pacific Bottom Water, penetration east around Hawaii: J. Geophys. Res., v. 76, p. 8089-8097.
Eittreim, S., Ewing, M., and Thorndike, E. M., 1969. Suspended matter along the continental margin of the North American Basin: Deep-Sea Res., v. 16, p. 613-624.

Ewing, M., Aitken, T., and Eittreim, S., 1968. Giant ripples in the Madagascar Basin: Trans. Am. Geophys. Union, v. 49, p. 218 (Abstract).

Ewing, M., Eittreim, S., Trucham, M., and Ewing, J. I., 1969. Sediment distribution in the Indian Ocean: Deep-Sea Res., v. 16, p. 231-248.

Ewing, J. I., Hollister, C., et al., 1970. Deep Sea Drilling Project. Leg 11: Geotimes, v. 15, p. 14-16.

Fillon, R. H., 1972. Evidence from the Ross Sea for widespread submarine erosion: Nature Phys. Sci., v. 238, p. 40-42.

Flemming, N. C. and Roberts, D. G., 1973. Tectonoeustatic changes in sea level and sea floor spreading: Nature, v. 243, p. 19-22.

Fox, P. J., Heezen, B. C., and Harian, A. M., 1968. Abyssal anti-dunes: Nature, v. 220, p. 470-472.

Frakes, L.A. and Kemp, E. M., 1972. Influence of continental positions on early Tertiary climates: Nature, v. 240 , p. $97-100$.

Gibson, T. G. and Towe, K. M., 1971. Eocene volcanism and the origin of Horizon A: Science, v. 172, p. 152-154.

Griffin, J. J. and Goldberg, E. D., 1963. Clay-mineral distributions in the Pacific Ocean: In The sea, v. 3: London (Interscience Publishers, John Wiley and Sons), p. 728-741.

Harris, T. F. W., 1972. Sources of the Agulhas current in the spring of 1964: Deep-Sea Res., v. 19, p. 633-650.

Hart, R. A., 1973. Geochemical and geophysical implications of the reaction between seawater and the oecanic crust: Nature, v. 243, p. 76-78.

Hayes, D. E., Frakes, L. A., et al., 1973. Deep Sea Drilling Project, Leg 28 Deep sea drilling in the southern ocean: Geotimes, v. 18 , p. 19-24.

Hays, J. D., Saito, T., Opdyke, N. D., and Burckle, L. H., 1969. Pliocene-Pleistocene sedimentation of the equatorial Pacific: Geol. Soc. Am. Bull., v. 80, p. 1481-1514.

Heezen, B. C. and Hollister, C. D., 1964. Deep Sea current evidence from abyssal sediments: Mar. Geol., v. 1, p. 141-174.

Heezen, B. C., MacGregor, I. D., et al., 1972. Deep Sea Drilling Project, Leg 20; Geotimes, v. 17, p. 10-14.

Hollister, C. D., and Elder, R. B., 1969. Contour current in the Weddell Sea: Deep-Sea Res., v. 16, p. 99-101.

Jacobs, S. S., Amos, A. F., and Bruchnausen, P. M., 1970. Ross Sea oceanography and Antarctic Bottom Water formation: Deep-Sea Res., v. 17, p. 935-936.

Johnson, D. A., 1972a. Eastward-flowing bottom currents along the Clipperton fracture: Deep-Sea Res., v. 19, p. 253-257.

1972b. Ocean floor erosion in the equatorial Pacific: Geol. Soc. Am. Bull., v. 83, p. 3121-3144.

Johnson, D. A. and Johnson, T. C., 1970. Sediment redistribution by bottom currents in the central Pacific: Deep-Sea Res., v. 17, p. 157-169.

Kenneth, J.P. and Brunner, C. A., 1972. Association between Antarctic glacial history and bottom water activity: Antarctic, September-October, p. 204-205.

Kenneth, J.P., Burns, R. E., et al., 1972. AustralianAntarctic continental drift, paleocirculation changes and Oligocene deep sea erosion: Nature Phys. Sci., v. 239, p. 51-55. 
Kuenen, Ph. H., 1950. Marine geology: New York (John Wiley \& Sons).

Laughton, A. S., McKenzie, D. P., and Sclater, J. G., 1972. The structure and evolution of the Indian Ocean: In Int. Geol. Congr. 24th, Montreal, Section 8, p. 65-73.

Le Pichon, X., 1960. The deep sea circulation in the southwest Indian Ocean: J. Geophys. Res., v. 65, p. 4061-4074.

Lisitzin, A.P., 1971a. Distribution of carbonate microfossils in suspension and in bottom sediments. In Funnel, B. M. and Riedel, W. R. (Eds.) The micropaleontology of the oceans: Cambridge (Cambridge University Press), p. 197-216.

1971b. Distribution of siliceous microfossils in suspension and in bottom sediments. In Funnel, B. M. and Riedel, W. R. (Eds.), The micropaleontology of oceans: Cambridge (Cambridge University Press), p. 173-196.

Luyendyck, B. P. Davies, T. A., et al., 1973. Across the southern Indian Ocean aboard Glomar Challenger: Geotimes, v. 18 , p. 16-19.

MacKenzie, F. T. and Garrels, R. M., 1966. Silicabicarbonate balance in the ocean and early diagenesis: J. Sed. Petrol., v. 36, p. 1075-1084.

McElhinny, M. W., 1970. Formation of the Indian Ocean: Nature, v. 228 , p. 977-979.

McKenzie, D. and Sclater, J. G., 1971. The evolution of the Indian Ocean since the Late Cretaceous: Geophys. J. Roy. Astro. Soc., v. 25 , p. 437-528.

Matson, P. H. and Pessagno, E. A., 1971. Caribbean Eocene volcanism and the extent of Horizon A: Science, v. 174, p. 138-139.

Olausson, E., 1961. Remarks on some Cenozoic core sequences from the Central Pacific with a discussion of the role of Coccolithophorids and Formaninifera in carbonate deposition: Medd. Oceanograf. Inst. Göteborg, v. 29, p. 1-35.

1971. Quaternary correlation and the geochemistry of oozes. In Funnell B. M., and Riedel, W. R. (Eds.), The micropaleontology of oceans: Cambridge (Cambridge University Press), p. 375-398.

Olausson, E., Bilal Ul Haq, U. Z., Karlson, G. B., and Olausson, I. U., 1971. Evidence in Indian Ocean cores of late Pleistocene changes in oceanic and atmospheric circulation. In Geologiska Föreningen i Stockholm Forbandlingar: v. 93 , p. 51-84.

Pimm, A. C. and Hayes, D. E., 1972. General synthesis. In Pimm, A. C., Hayes, D. E., et al., Initial Reports of the Deep Sea Drilling Project, Volume 14: Washington (U. S. Government Printing Office), p. 955.

Rex, R. W., 1970. X-ray mineralogy studies - Leg 3. In Maxwell, A. E., von Herzen, R., et al., Initial Reports of the Deep Sea Drilling Project, Volume 3: Washington (U. S. Government Printing Office), p. 509-587.

Rex, R. W. and Murray, B., 1970. X-ray mineralogy studies - Leg 4. In Bader, R. G., Gerard, R. D., et al., Initial Reports of the Deep Sea Drilling Project, Volume 4,
Washington (U. S. Government Printing Office), p. 325-374

Saito, T. and Fray, C., 1964. Cretaceous and Tertiary sediments from the southwestern Indian Ocean: Geol. Soc. Am. (Special Papers), v. 82, p. 171-172.

Sclater, J. G. and Harrison, C. G. A., 1971. Elevation of Mid-Ocean Ridges and the evolution of the Southwest Indian Ridge: Nature, v. 230, p. 175-177.

Sverdrup, H. U., Johnson, M. W., and Fleming, R. H., 1942. The Oceans - their physics, chemistry and general biology: New York. (Prentice Hall, Inc. Publishers).

Tappan, H., 1968. Primary production, isotopes, extinctions and the atmosphere: Palaegeogr. Palaeoclimatol. Palaeoecol., v. 4, p. 187-210.

Tazieff, H., 1972. Les volcans et la dérive des continents. 1 vol: Vendome. (Press Universitaire de France).

Tchernia, P., Le Floch, J., and Lacombe, H., 1951. Contribution á l'étude de l'océan Indian et la secteur adjacent de l'océan Atlantique: Bull. Inform. COEC, v. $3,65 \mathrm{p}$.

Tracey, J. I., Sutton, G. H., et al., 1970. Deep Sea Drilling Project. Leg 8: Geotimes, v. 15, p. 14-15.

Uschakova, M. G., 1971. Coccoliths in suspension and in the surface layer of sediment in the Pacific Ocean: In Funnell, B. M. and Riedel, W. R. (Eds.) The micropaleontology of oceans: Cambridge (Cambridge University Press), p. 245-251.

van Andel, T. H., Heath, G. R., et al., 1971. Deep Sea Drilling Project, Leg 16: Geotimes, v. 16 (June 1971), p. 12-14.

von der Borch, C. C., Galehouse, J., and Nesteroff, W. D. 1971a. Silicifed limestone - chert. sequences cored during Leg 8 of the Deep Sea Drilling Project. A petrologic study. In Tracey, J. I., and Sutton, G. H., et al. Initial Reports of the Deep Sea Drilling Project, Volume 8; Washington (U. S. Government Printing Office), p. 819-827.

1971 b. Iron-rich sediments cored during Leg 8 of the Deep Sea Drilling Project. In Tracey, J. I., Sutton, G. H., et al. Initial Reports of the Deep Sea Drilling Project, Volume 8: Washington (U. S. Government Printing Office), p. 829-833.

Warren, B. A., 1971. Evidence for a deep western boundary current in the south Indian Ocean: Nature Phys. Sci., v. 229 , p. 18-19.

Watkins, N. D. and Kenneth, J. P., 1971. Antarctic Bottom Water: major change in the velocity during the Late Cenozic between Australia and Antarctica: Science, v. 173 , p. $813-815$

Weaver, M. and Wise, S. W., 1972. Deep sea cristobalite chert and authigenic mineral comprising fine blades which grow in spherules: Nature Phys. Sci., v. 237, p. 56-57.

Wise, S. W. and Hsü, K. S., 1971. Genesis and lithification of a deep sea chalk: Eclog. Geol. Helv., v. 64, p. 273-278.

Wise, S. W., Buie, B. F., and Weaver, F. M., 1971. Chemically precipitated sedimentary cristobalite and the origin of chert: Eclog. Geol. Helv., v. 65/1, p. 157-163. 
PLATE 1

Silicified Chalk and Chert, broken surfaces of a silicified chalk - chert bed from Sample 245-7, CC.

Figure 1 Agglomerate of cristobalite spherules inside a foraminifera chamber. Note marks (external moulds) of the removed chamber wall fragment.

Figure 2 Detail of Figure 1. External moulds are clearly visible as are cristobalite blades constituting the spherules.

Figure 3 One isolated cristobalite spherule inside a foraminifera chamber. Calcite elements of the foraminifera are recrystallized or at least overgrown.

Figure 4 Broken foraminifera test containing aggregates of cristobalite spherules inside its initial chambers.

Figure 5 Detail of Figure 4 showing marks of micarb, roots of cristobalite blades, and filaments of amorphous (?) silica.

Figure 6 Detail of Figure 5, with magnification of bridging fibrous cristobalite apparently cementing together individual spherules. 
PLATE 1
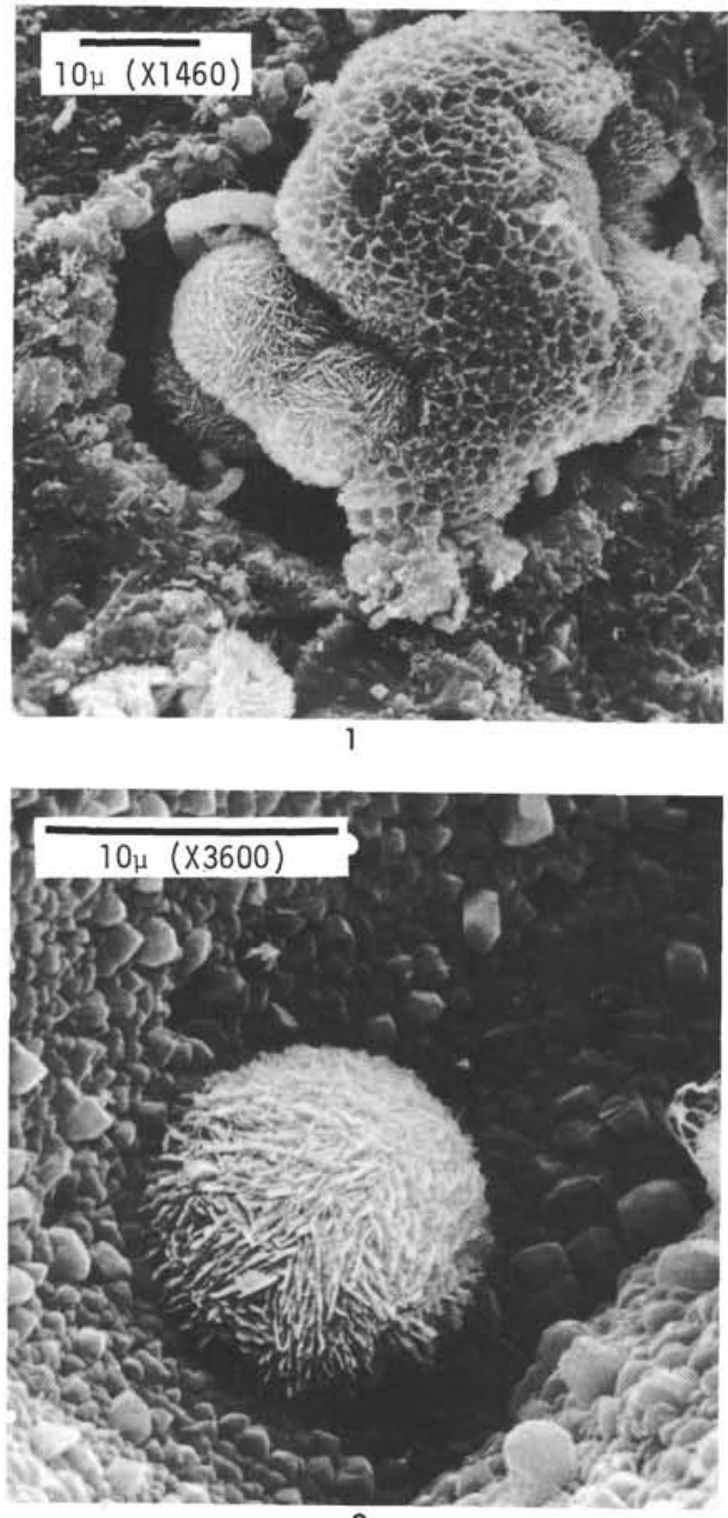

3

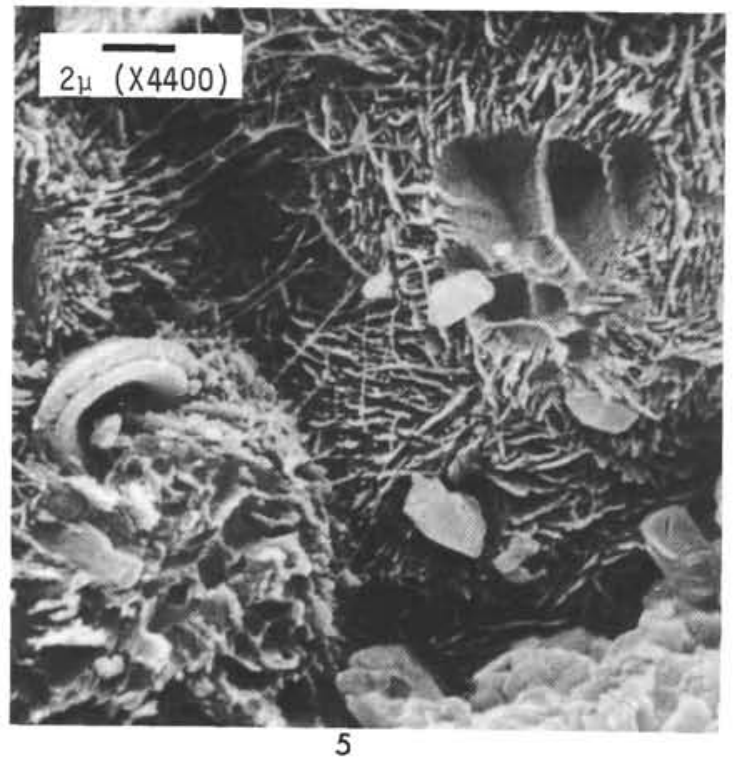

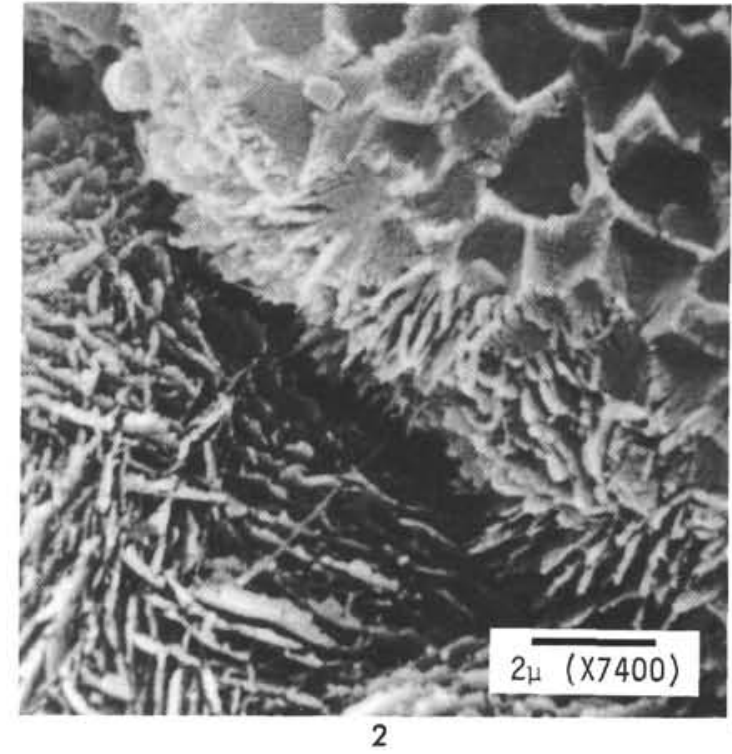
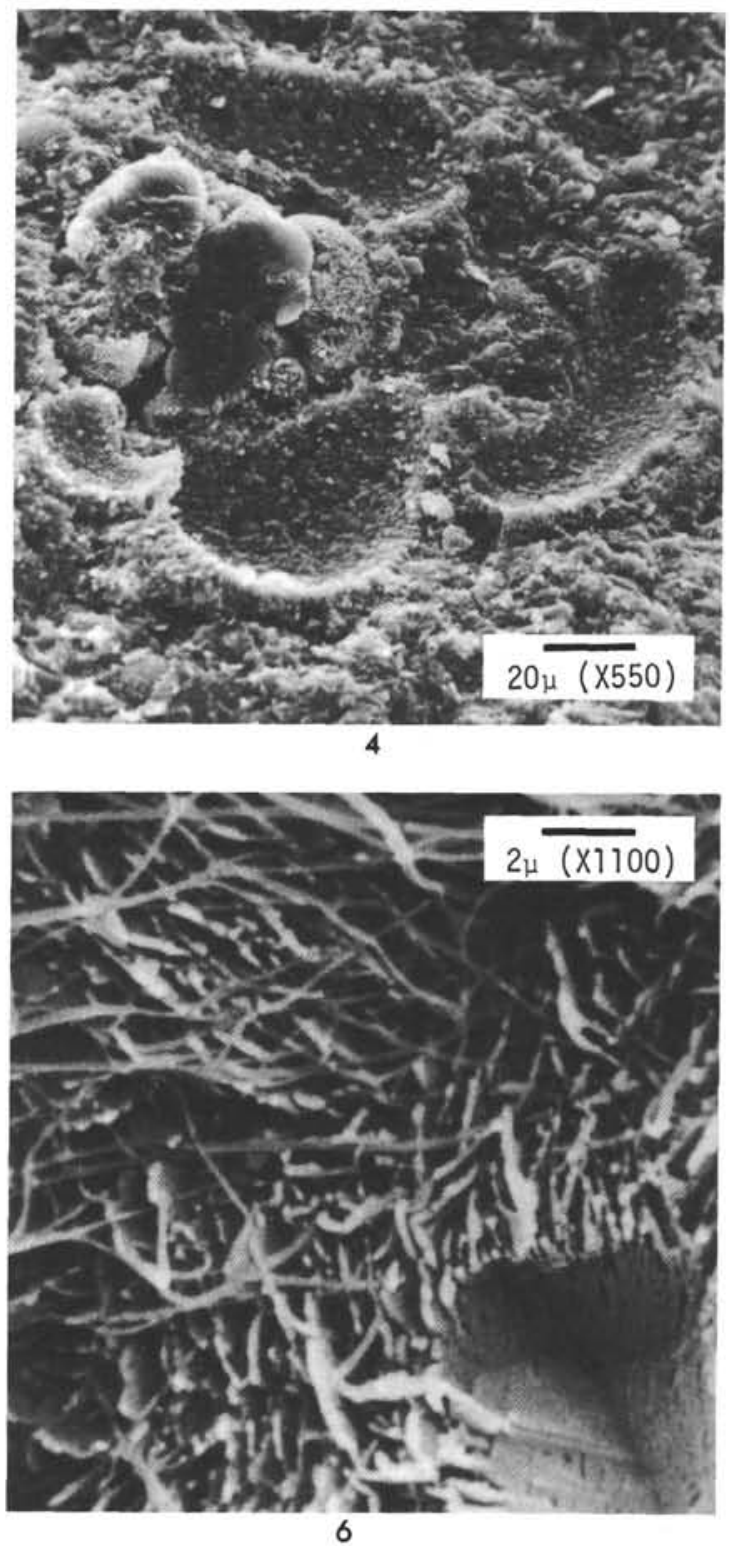


\section{PLATE 2}

Silicified Chalk and Chert

Figure 1

Figure 3

Figure 4

Figure 5

Figure 6
Broken surfaces of Sample 245-7, CC. Numerous cristobalite spherules close to the chalk-chert boundary. Note again bridging filaments which form a feltering linking spherules together.

Broken surfaces of Sample 245-7, CC. Another aspect of cristobalite spherule arrangement; blades form sheaf-like features more or less cross-laced.

Sawed section of Sample 245-7-2, 116-128 cm (chalk part). Nannofossils are cemented together partly with disordered cristobalite blades.

Detail of Figure 3, magnification of the cristobalitic cement.

Sawed section of Sample 245-7-2, 116-128 cm (true chert part). Ghost of foraminifera; the chamber showed on the picture is entirely made of massive silica. Around, subsisting micarb is visible.

Another aspect of the same sample, from the chert zone with massive silica. 


\section{PLATE 2}
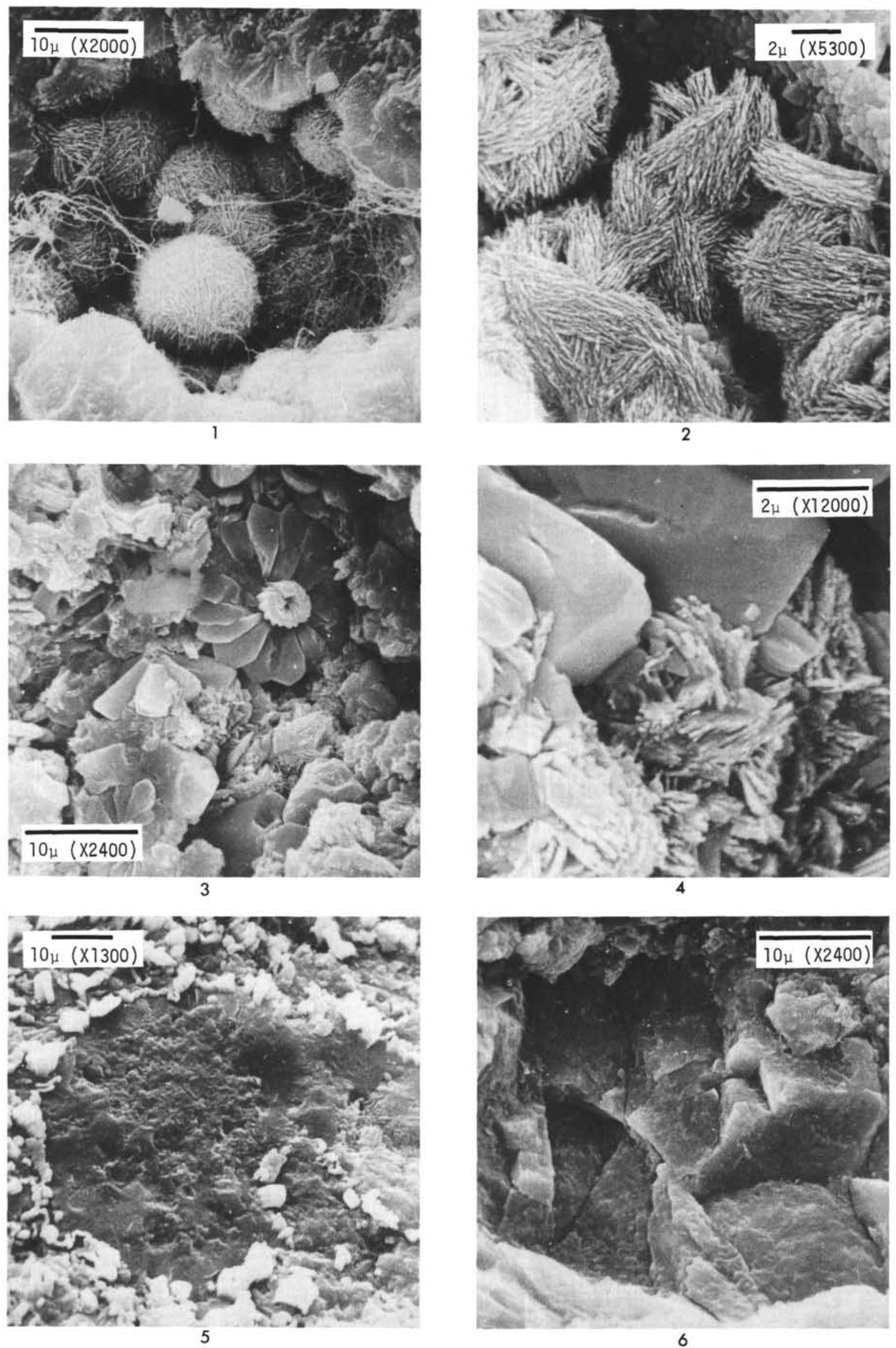


\section{PLATE 3}

Ferromanganoan Basal Deposits from Site 245

(Sample 245-16, CC).

Figure 1 General view of a broken surface. Foraminiferal remains are fairly abundant with nannofossils, micarb, and clay.

Figure 2 Recrystallized foraminifera remains. An important part of the micarb could possibly originate from the desaggregation of such recrystallized foraminifera fragments.

Figure 3 Another view showing abundance of foraminifera with micarb and calcite (or dolomite) rhombs.

Figure 4 Undetermined spherulitic agglomerate presumably considered as cemented micarb.

Figure 5 Undetermined agglomerate of very fine particles which are possible amorphous iron-manganese oxides.

Figure 6 Detail of Figure 5 with magnification showing the size of the elemental particles to be far less than $1 \mu$. 


\section{PLATE 3}
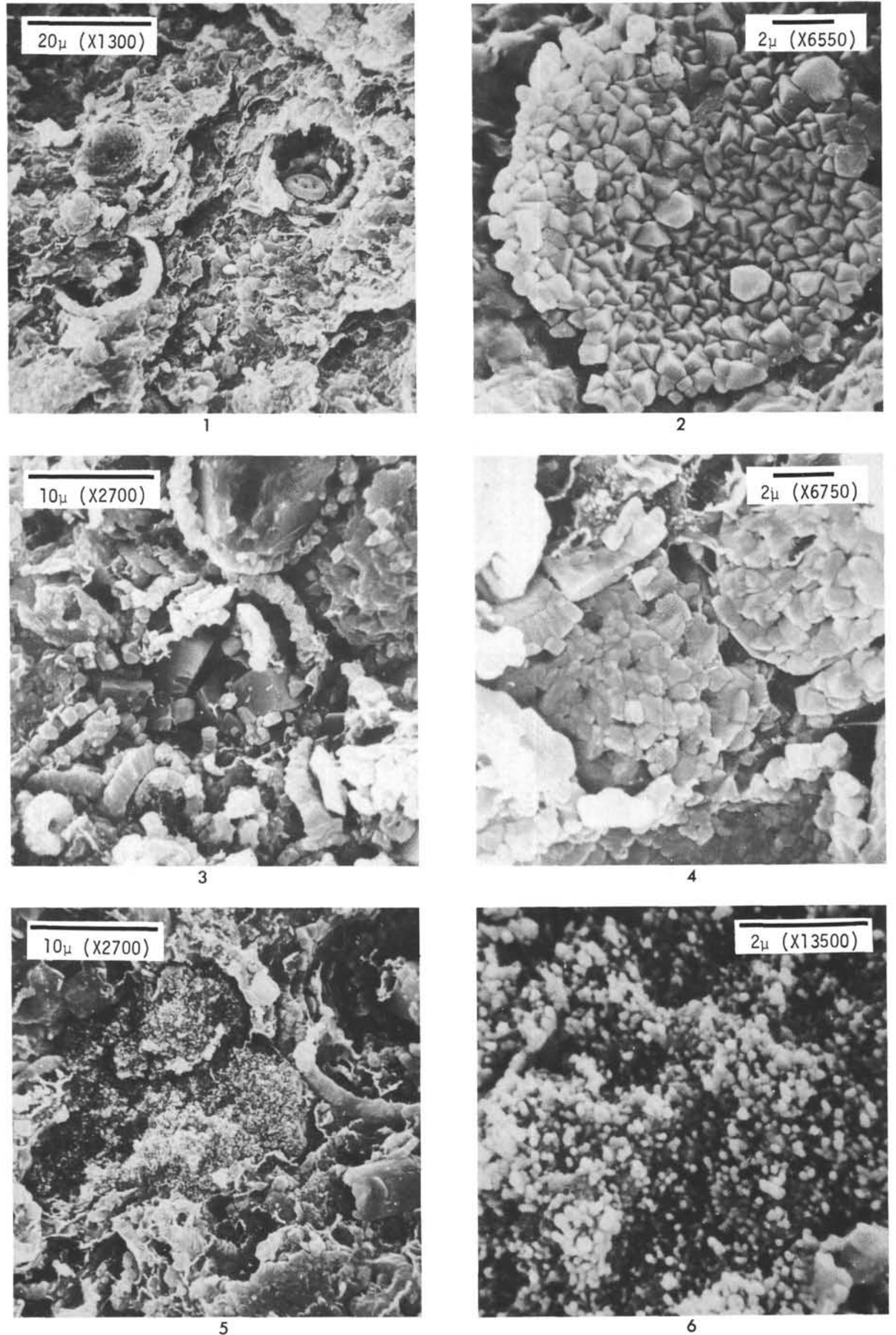


\section{PLATE 4}

Miscellaneous Features.

Figure 1 Ferromanganoan deposits (continued), Sample $245-16$, CC. View of a recrystallized foraminifera fragment. On the right middle side of the picture is a crystal which might be clinoptilolite. Calcitic rhombs are abundant.

Figure 2 Detail view of Figure 1, showing the postdepositional authigenesis of a calcitic rhomb as evidenced by the partial nannofossil inclusion.

Figure 3 Pyritic burrow cast (Sample 242-2-2, 64-67 cm). The internal wall is made of euhedral crystals of pyrite.

Figure 4 Another view of the same sample with a different aspect of euhedral pyrite.

Figure $5 \quad$ Volcanic ash (Sample 245-29-2, $80 \mathrm{~cm}$ ). Devitrification features are clearly visible on the surface of the shards.

Figure 6 Detail view of Figure 5; magnification of the altered surface of a partly devitrified shard. 
PLATE 4
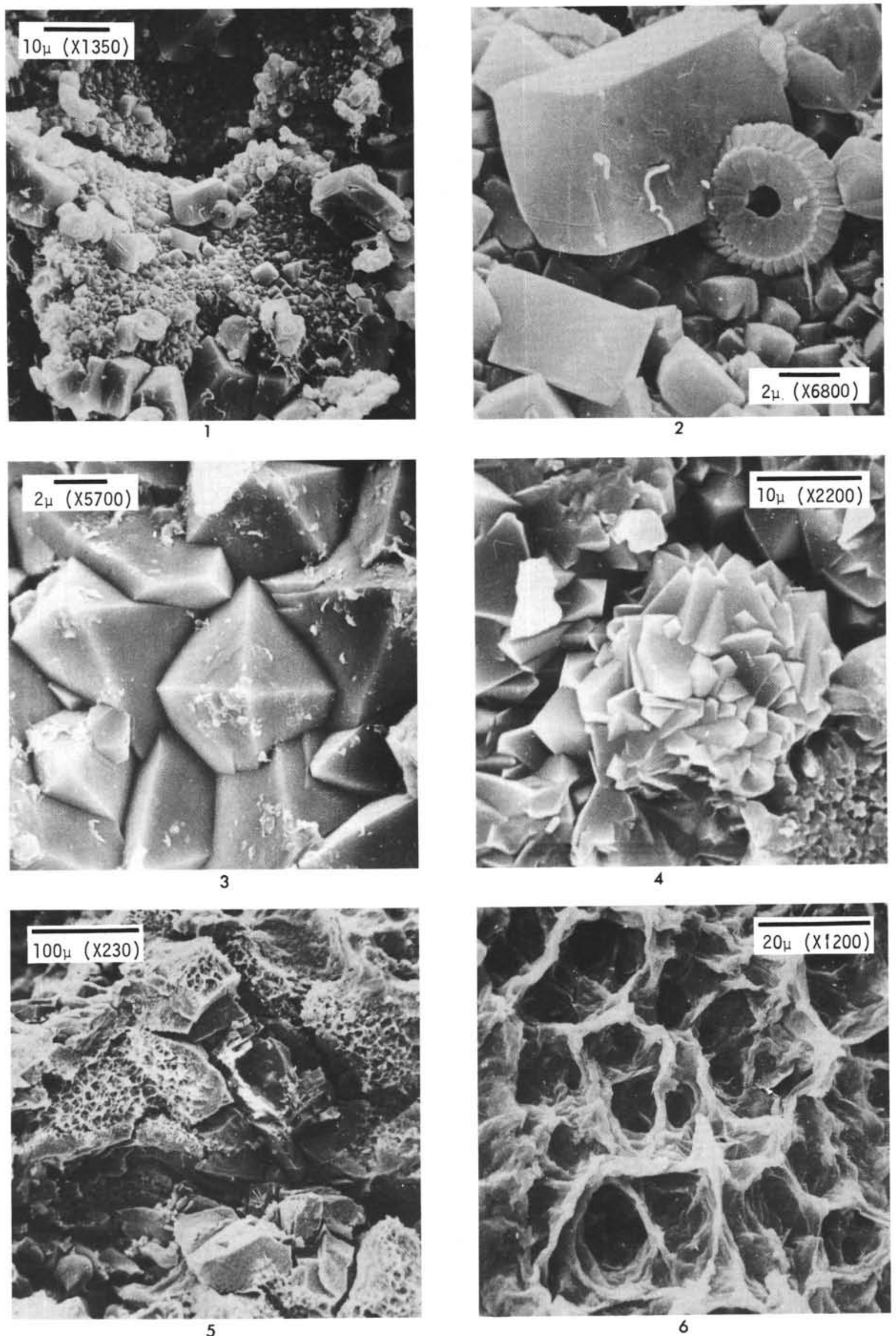